\title{
Synthesis, Antimycobacterial Evaluation and Docking Studies of Some 7-Methyl-5,6,7,8-tetrahydropyrido $\left[4^{\prime}, 3^{\prime}: 4,5\right]$ thieno[2,3-d]pyrimidin-4(3H)- ones
}

\author{
Narender Malothu, ${ }^{a}$ Umasankar Kulandaivelu, ${ }^{b}$ Malathi Jojula, ${ }^{c}$ Shravan Kumar Gunda, ${ }^{d}$ and \\ Raghuram Rao Akkinepally*,a,† \\ ${ }^{a}$ Medicinal Chemistry Division, University College of Pharmaceutical Sciences; Kakatiya University, \\ Warangal-506009, India: ${ }^{b}$ KL College of Pharmacy, KLEF Deemed to Be University; Vaddeswaram, Guntur-522502, \\ India: ${ }^{c}$ Department of Microbiology, Sri Shivani College of Pharmacy; Warangal-506009, India: and ${ }^{d}$ Bioinformatics \\ Division, Osmania University; Hyderabad-500007, India.
}

Received December 12, 2017; accepted July 10, 2018

Two series of 3 -substituted-7-methyl-5,6,7,8-tetrahydropyrido $\left[4^{\prime}, 3^{\prime}: 4,5\right]$ thieno[2,3-d]pyrimidin-4(3H)one $(6 a-k)$ and 3 -substituted-7,2-dimethyl-5,6,7,8-tetrahydropyrido[4',3':4,5] thieno[2,3-d]pyrimidin-4(3H)one $(7 \mathrm{a}-\mathrm{k})$ derivatives were synthesized and characterized using spectral data i.e., IR, ${ }^{1} \mathrm{H}-,{ }^{13} \mathrm{C}-\mathrm{NMR}$, Mass and CHN elemental analyses. The synthesized compounds were evaluated for antibacterial activity against each of two strains of Gram-positive (Bacillus subtilis and Staphylococcus aureus) and Gram-negative (Escherichia coli and Klebsiella pneumoniae) bacteria and antimycobacterial activity screened against two strains i.e., Mycobacterium tuberculosis (MTB) H37Rv and an isoniazid-resistant clinical sample. Further to validate potentiality of our design was analyzed using molecular docking studies by taking crystal structure of MTB pantothenate synthetase (MTB-PS) (PDB: 3IVX). In this study, some compounds 6k (Minimum Inhibitory Concentration (MIC): MIC-22 $\mu \mathrm{M}$ ), 7d (MTB: MIC-22 $\mu \mathrm{M}$ ) and 7k (MTB: MIC-11 $\mu \mathrm{M})$ showed potential antibacterial and antimycobacterial activities.

Key words antimycobacterial activity; isoniazid; Mycobacterium tuberculosis H37Rv; pantothenate synthetase; 5,6,7,8-tetrahydropyrido $\left[4^{\prime}, 3^{\prime}: 4,5\right]$ thieno(2,3- $\left.d\right)$ pyrimidine-4(3H)-one

Tuberculosis (TB) is considered as a serious public health threat worldwide, as current therapy is limited due to the emergence of multi-drug resistance (MDR) and extensively drug resistance (XRD), regimen therapy, and severe side effects of existing drugs and long duration of therapy.,2) Moreover, TB is more widespread due to its coincidence with AIDS and Human Immunodeficiency Virus (HIV) coinfection. ${ }^{3)}$ Development of drug resistance (MDR and XDR) to widely used first line drugs is an obstacle in the treatment and control programs of this disease. Resistance to isoniazid (INH) is more predominant in MDR TB as about $30 \%$ of clinical isolates found to be resistant to it, worldwide. Several decades of extensive research resulted in identification and development of only few drugs such as bedaquiline and delamanide, which were approved as drugs of choice in drug resistant (MDR and XDR) TB. Several other novel drug candidates for drug resistant TB such as oxazolidinones (linezolid), nitroimidazoles (PA-824) and ethylenediamines (SQ-109) etc., are currently under clinical development. ${ }^{4)}$ There is an urgent need of shorter and simple regimens, effective, safe and well tolerated drugs for drug-resistant and drug-susceptible TB.

In view of development of hetero-fused thieno[2,3- $d$ ]pyrimidine-4(3H)-one analogues various recent reports prompted us to continue our studies by retaining 4,5,6,7-tetrahydrothieno[2,3-c]pyridine as basic nucleus. ${ }^{5)}$ It was a common feature in some reported Mycobacterium tuberculosis Pantothenate synthetase (MTB-PS) inhibitors

${ }^{\dagger}$ Present address: National Institute of Pharmaceutical Education and Research (NIPER), Sector 67; S.A.S. Nagar (Mohali)-160 062, Punjab, India. such as 6-benzyl-4,5,6,7-tetrahydrothieno[2,3-c]pyridine-3carboxamide (A, SID 92104095; $\mathrm{IC}_{50}=3.3 \mu \mathrm{g} / \mathrm{mL}$ ), ${ }^{6}$ 6-acetyl4,5,6,7-tetrahydro thieno[2,3-c]pyridine-3-carboxamide (B, SID 92097880; $\left.\left.\quad \mathrm{IC}_{50}=0.5 \mu \mathrm{g} / \mathrm{mL}\right)\right)^{6}$ derivatives, as described earlier. ${ }^{5)}$ In addition, Rashmi et al. reported potentiality of some thieno[2,3-d]pyrimidines (C) on $\mathrm{My}$ cobacterium. ${ }^{7)}$ Narayana et al. reported the antibacterial activity of some 4,5,6,7-tetrahydro[1]benzothieno[2,3-d]pyridimidine-4(3H)-ones (D). ${ }^{8)}$ These studies proved the essentiality of 4,5,6,7-tetrahydrothieno[2,3-c]pyridine (A, B) nucleus and arylidineamino side chain at 3rd or 4th position in $\mathrm{C}$ and $\mathrm{D}$ in their antibacterial and antimycobacterial activity (Fig. 1). In the design of molecules, both the structural features were adopted. The 3-amino-7-methyl-5,6,7,8tetrahydropyrido $\left[4^{\prime}, 3^{\prime}: 4,5\right]$ thieno $[2,3-d]$ pyrimidin-4(3H)-one was considered as a key structure for the synthesis. The bulky (benzyl) group present in the previous series ${ }^{5)}$ was substituted with a small (methyl) group at 7th position of 5,6,7,8-tetrahydropyrido $\left[4^{\prime}, 3^{\prime}: 4,5\right]$ thieno[2,3- $\left.d\right]$ pyrimidine nucleus. Aurelio et al. also reported the allosteric modulation effects of 2-amino-4,5,6,7-tetrahydrothieno[2,3-c]pyridines on $\mathrm{A}_{1}$ adenosine receptor. ${ }^{9)}$ Modifications at 7 th position with small and medium pharmacophores such as $N$-methyl, $N$-benzyl and $N$-ethoxycarbonyl resulted differences in their biological activity. As per their studies, it was due to increase in basicity with $N$-methyl substitution. Although, the structure activity relationship was described for $A_{1}$ adenosine receptor modulation, the significance of 7 th substitution was considered in this study and attempted with these modifications perhaps it could show a better antimycobacterial activity. In 
this direction our studies are continued on the development of novel hetero-fused thieno[2,3- $d$ ] pyrimidine analogues against drug-resistant TB (INH-resistant TB). ${ }^{5)}$ Two series of molecules 7-methyl-3-(substituted-aryledineamino)-5,6,7,8tetrahydropyrido $\left[4^{\prime}, 3^{\prime}: 4,5\right]$ thieno $[2,3-d]$ pyrimidin-4(3H)-ones $(\mathbf{6 a}-\mathbf{k})$ and 2,7-dimethyl-3-(substituted-aryledineamino)2-methyl-5,6,7,8-tetrahydropyrido $\left[4^{\prime}, 3^{\prime}: 4,5\right]$ thieno[2,3- $\left.d\right]$ pyrim idin-4(3H)-ones $(\mathbf{7} \mathbf{a}-\mathbf{k})$ have been synthesized and evaluated for their antitubercular activity. Initial antibacterial screening was performed against each of two Gram-positive (Bacillus subtilis and Staphylococcus aureus) and Gram-negative (Escherichia coli and Klebsiella pneumonia) bacteria. The antimycobacterial activity was conducted for selected compounds based on results obtained in initial antibacterial screening. Mycobacterium tuberculosis (MTB) H37Rv and an INH-resistant clinical sample were used as standard and test organisms.

Further, in silico binding interactions of these analogues were studied using target protein MTB-PS (PDB: 3IVX) with the help of Molegro Virtual Docker (MVD) software. These investigations indicated that some of the compounds expressed promising in vitro antibacterial and antimycobacterial activities against the test strains.

\section{Results and Discussion}

Chemistry The synthesis of target compounds 7-methyl-3-(substituted-aryledineamino)-5,6,7,8-tetrahydropyrido $\left[4^{\prime}, 3^{\prime}: 4,5\right]$ thieno[2,3- $\left.d\right]$ pyrimidin-4(3H)-ones $(\mathbf{6 a}-$ k) and 2,7-dimethyl-3-(substituted-aryledineamino)-5,6,7,8tetrahydropyrido $\left[4^{\prime}, 3^{\prime}: 4,5\right]$ thieno $[2,3-d]$ pyrimidin-4(3H)-ones $(7 \mathbf{a}-\mathbf{k})$ was achieved as shown in Chart 1 .

The requisite key starting material 3 was synthesized by Gewald Reaction (GR) using N-methyl-4-piperidone (1), elemental sulphur and ethylcyanoacetate (2) by following a

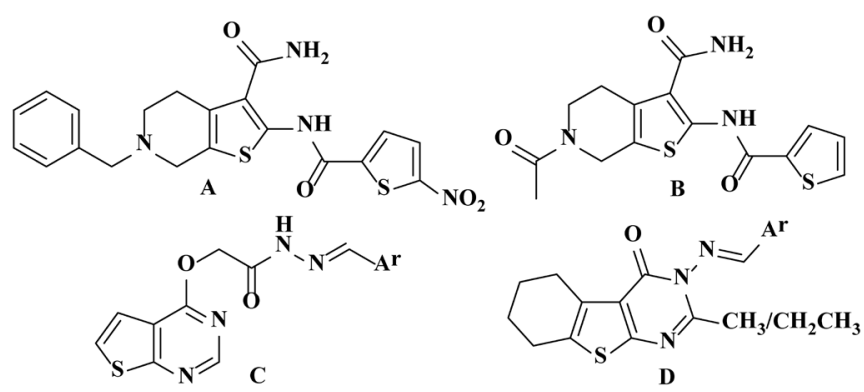

Fig. 1. General Structures of Some Potent Antibacterial Agents (A, B: MTB-PS Inhibitors) reported procedure ${ }^{9,10)}$ which gave the product in $85 \%$ of yield. The compound $\mathbf{3}$ was converted to iminoester derivatives by heating under reflux in triethylorthoformate and triethylorthoacetate, which gave thick brown oily products $\mathbf{4 a}$ and $\mathbf{4 b}$, respectively. Compounds $\mathbf{4 a}$ and $\mathbf{4 b}$ were treated with hydrazine hydrate ${ }^{5,11-13)}$ to get their cyclized products $\mathbf{5 a}$ and 5b. In IR spectrum compound $\mathbf{5 b}$ showed two characteristic signals at $3450 \mathrm{~cm}^{-1}$ and $3300 \mathrm{~cm}^{-1}$ assignable to $\mathrm{N}-\mathrm{H}$ stretching for $3-\mathrm{NH}_{2}$ group and another signal at $1670 \mathrm{~cm}^{-1}$ assignable to $\mathrm{C}=\mathrm{O}$ stretching of carbonyl group of pyrimidine ring. The ${ }^{1} \mathrm{H}-\mathrm{NMR}$ spectrum of compound $\mathbf{5 b}$ showed a singlet at $\delta=2.20 \mathrm{ppm}$ which could be assignable to methyl $\left(2-\mathrm{CH}_{3}\right)$ group of pyrimidinone ring. The presence of another broad singlet at the $\delta=5.13 \mathrm{ppm}$ could be assignable to primary amino functionality.

Table 1. Physical Data of Synthesized Compounds $6 \mathbf{a}-\mathbf{k}$ and $\mathbf{7 a}-\mathbf{k}$<smiles></smiles>

\begin{tabular}{|c|c|c|c|c|c|}
\hline $\begin{array}{l}\text { Comp. } \\
\text { Code }\end{array}$ & $\mathrm{R}$ & $\mathrm{R}^{1}$ & $\begin{array}{l}\text { Mol. Wt. } \\
\text { (M) }\end{array}$ & $\begin{array}{l}\text { Melting range } \\
\left({ }^{\circ} \mathrm{C}\right)\end{array}$ & $\begin{array}{c}\text { Yield } \\
(\%)\end{array}$ \\
\hline $6 \mathbf{a}$ & $\mathrm{H}$ & $-\mathrm{C}_{6} \mathrm{H}_{5}$ & 324 & $164-166$ & 87 \\
\hline $6 \mathbf{b}$ & $\mathrm{H}$ & $4-\mathrm{ClC}_{6} \mathrm{H}_{4}$ & 358 & $196-198$ & 78 \\
\hline $6 c$ & $\mathrm{H}$ & $4-\mathrm{FC}_{6} \mathrm{H}_{4}$ & 343 & $180-182$ & 64 \\
\hline 6d & $\mathrm{H}$ & $4-\mathrm{CNC}_{6} \mathrm{H}_{4}$ & 350 & $236-238$ & 67 \\
\hline $6 e$ & $\mathrm{H}$ & 4- $-\mathrm{OCH}_{3} \mathrm{C}_{6} \mathrm{H}_{4}$ & 354 & $168-170$ & 80 \\
\hline $6 f$ & $\mathrm{H}$ & $4-\mathrm{OHC}_{6} \mathrm{H}_{4}$ & 340 & $220-222$ & 65 \\
\hline $6 \mathrm{~g}$ & $\mathrm{H}$ & $3,4,5-\left(\mathrm{OCH}_{3}\right)_{3} \mathrm{C}_{6} \mathrm{H}_{2}$ & 414 & $192-194$ & 67 \\
\hline $6 \mathrm{~h}$ & $\mathrm{H}$ & 2- $-\mathrm{NO}_{2} \mathrm{C}_{6} \mathrm{H}_{4}$ & 369 & $159-161$ & 72 \\
\hline $6 \mathbf{i}$ & $\mathrm{H}$ & Thiophene-2-yl & 330 & $120-122$ & 66 \\
\hline $6 \mathbf{j}$ & $\mathrm{H}$ & Furan-2-yl & 314 & $156-158$ & 80 \\
\hline $6 k$ & $\mathrm{H}$ & $2,6-\mathrm{Cl}_{2} \mathrm{C}_{6} \mathrm{H}_{3}$ & 392 & $190-192$ & 82 \\
\hline $7 \mathbf{a}$ & $\mathrm{CH}_{3}$ & $-\mathrm{C}_{6} \mathrm{H}_{5}$ & 338 & $185-187$ & 85 \\
\hline $7 \mathrm{~b}$ & $\mathrm{CH}_{3}$ & $4-\mathrm{ClC}_{6} \mathrm{H}_{4}$ & 372 & $153-155$ & 71 \\
\hline $7 \mathrm{c}$ & $\mathrm{CH}_{3}$ & $4-\mathrm{FC}_{6} \mathrm{H}_{4}$ & 355 & $230-232$ & 65 \\
\hline $7 d$ & $\mathrm{CH}_{3}$ & $4-\mathrm{CNC}_{6} \mathrm{H}_{4}$ & 363 & $200-202$ & 68 \\
\hline $7 e$ & $\mathrm{CH}_{3}$ & 4- $-\mathrm{OCH}_{3} \mathrm{C}_{6} \mathrm{H}_{4}$ & 368 & $173-175$ & 82 \\
\hline $7 f$ & $\mathrm{CH}_{3}$ & $4-\mathrm{OHC}_{6} \mathrm{H}_{4}$ & 354 & $218-220$ & 76 \\
\hline $7 \mathrm{~g}$ & $\mathrm{CH}_{3}$ & $3,4,5-\left(\mathrm{OCH}_{3}\right)_{3} \mathrm{C}_{6} \mathrm{H}_{2}$ & 428 & $198-200$ & 70 \\
\hline $7 \mathrm{~h}$ & $\mathrm{CH}_{3}$ & $2-\mathrm{NO}_{2} \mathrm{C}_{6} \mathrm{H}_{4}$ & 383 & $154-156$ & 78 \\
\hline $7 \mathbf{i}$ & $\mathrm{CH}_{3}$ & Thiophene-2-yl & 312 & $178-180$ & 70 \\
\hline $7 \mathbf{j}$ & $\mathrm{CH}_{3}$ & Furan-2-yl & 328 & $172-174$ & 79 \\
\hline $7 k$ & $\mathrm{CH}_{3}$ & $2,6-\mathrm{Cl}_{2} \mathrm{C}_{6} \mathrm{H}_{3}$ & 406 & $181-183$ & 80 \\
\hline
\end{tabular}

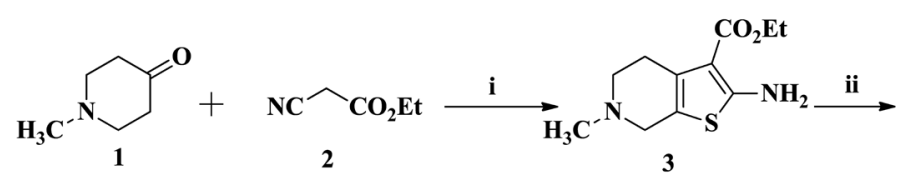<smiles>[R4]C=Nn1c([R])nc2sc3c(c2c1=O)CCN(CC#CCCC)C3</smiles>

i) $\mathrm{S}_{8}$, morpholine, ethanol, reflux, 1-2h; ii) Triethylorthoformate/triethylorthoacetate, reflux, 2-4h; iii) $\mathrm{NH}_{2} \mathrm{NH}_{2} \mathrm{H}_{2} \mathrm{O}$, ethanol, stir, 1-2 h; iv) $\mathrm{R}^{1} \mathrm{CHO}$, glacial CH $\mathrm{COOH}_{3}$ ethanol, reflux, $12 \mathrm{~h}$.

Chart 1. General Chart for Synthesis of Compounds $6 \mathbf{a}-\mathbf{k}$ and $7 \mathbf{a}-\mathbf{k}$ 
Table 2. Antibacterial Activity (MIC) Data of Test Compounds $\mathbf{6 a}-\mathbf{k}$ and $\mathbf{7 a}-\mathbf{k}$

\begin{tabular}{|c|c|c|c|c|c|c|}
\hline \multirow[b]{2}{*}{ Comp. Code } & \multirow[b]{2}{*}{$\mathrm{R}$} & \multirow[b]{2}{*}{$\mathrm{R}^{1}$} & \multicolumn{4}{|c|}{$\operatorname{MIC}(\mu \mathrm{M})$} \\
\hline & & & $\begin{array}{l}\text { S. aureus } \\
\text { MTCC } 96\end{array}$ & $\begin{array}{l}\text { B. subtilis } \\
\text { MTCC } 441\end{array}$ & $\begin{array}{c}\text { E. coli } \\
\text { MTCC } 443\end{array}$ & $\begin{array}{l}\text { K. pneumoniae } \\
\text { MTCC } 109\end{array}$ \\
\hline $6 a$ & $\mathrm{H}$ & $-\mathrm{C}_{6} \mathrm{H}_{5}$ & NA & NA & NA & NA \\
\hline $6 b$ & $\mathrm{H}$ & $4-\mathrm{ClC}_{6} \mathrm{H}_{4}$ & 43.64 & 43.64 & 21.82 & 87.29 \\
\hline $6 c$ & $\mathrm{H}$ & $4-\mathrm{FC}_{6} \mathrm{H}_{4}$ & 46 & 46 & 23 & 46 \\
\hline $6 d$ & $\mathrm{H}$ & $4-\mathrm{CNC}_{6} \mathrm{H}_{4}$ & 48 & 48 & 24 & 48 \\
\hline $6 e$ & $\mathrm{H}$ & $4-\mathrm{OCH}_{3} \mathrm{C}_{6} \mathrm{H}_{4}$ & 44.1 & 88.2 & 44.1 & NA \\
\hline 6f & $\mathrm{H}$ & $4-\mathrm{OHC}_{6} \mathrm{H}_{4}$ & NA & NA & NA & NA \\
\hline $6 \mathrm{~g}$ & $\mathrm{H}$ & $3,4,5-\left(\mathrm{OCH}_{3}\right)_{3} \mathrm{C}_{6} \mathrm{H}_{2}$ & NA & NA & NA & NA \\
\hline $6 h$ & $\mathrm{H}$ & $2-\mathrm{NO}_{2} \mathrm{C}_{6} \mathrm{H}_{4}$ & 84 & 84 & 84 & 84 \\
\hline $6 \mathbf{i}$ & $\mathrm{H}$ & Thiophene-2-yl & 48 & 48 & 24 & 48 \\
\hline $6 \mathbf{j}$ & $\mathrm{H}$ & Furan-2-yl & 98 & 98 & 98 & $<98$ \\
\hline $6 k$ & $\mathrm{H}$ & $2,6-\mathrm{Cl}_{2} \mathrm{C}_{6} \mathrm{H}_{3}$ & 22 & 22 & 11 & 22 \\
\hline $7 \mathbf{a}$ & $\mathrm{CH}_{3}$ & $-\mathrm{C}_{6} \mathrm{H}_{5}$ & NA & NA & NA & NA \\
\hline $7 \mathbf{b}$ & $\mathrm{CH}_{3}$ & 4- $\mathrm{ClC}_{6} \mathrm{H}_{4}$ & 44 & 44 & 22 & 44 \\
\hline $7 c$ & $\mathrm{CH}_{3}$ & $4-\mathrm{FC}_{6} \mathrm{H}_{4}$ & 46 & 46 & 23 & 46 \\
\hline $7 d$ & $\mathrm{CH}_{3}$ & $4-\mathrm{CNC}_{6} \mathrm{H}_{4}$ & 24 & 24 & 12 & 24 \\
\hline $7 e$ & $\mathrm{CH}_{3}$ & $4-\mathrm{OCH}_{3} \mathrm{C}_{6} \mathrm{H}_{4}$ & 44 & 44 & 22 & 44 \\
\hline $7 f$ & $\mathrm{CH}_{3}$ & $4-\mathrm{OHC}_{6} \mathrm{H}_{4}$ & NA & NA & NA & NA \\
\hline $7 g$ & $\mathrm{CH}_{3}$ & $3,4,5-\left(\mathrm{OCH}_{3}\right)_{3} \mathrm{C}_{6} \mathrm{H}_{2}$ & NA & NA & NA & NA \\
\hline $7 \mathbf{h}$ & $\mathrm{CH}_{3}$ & $2-\mathrm{NO}_{2} \mathrm{C}_{6} \mathrm{H}_{4}$ & 162 & 162 & 162 & 162 \\
\hline $7 \mathbf{i}$ & $\mathrm{CH}_{3}$ & Thiophene-2-yl & 28 & 28 & 28 & 28 \\
\hline $7 \mathbf{j}$ & $\mathrm{CH}_{3}$ & Furan-2-yl & 50 & 50 & 50 & 50 \\
\hline $7 \mathbf{k}$ & $\mathrm{CH}_{3}$ & $2,6-\mathrm{Cl}_{2} \mathrm{C}_{6} \mathrm{H}_{3}$ & 21 & 21 & 10 & 21 \\
\hline Std & - & - & $<1$ & $<1$ & $<1$ & $<1$ \\
\hline Ctrl & - & - & NA & NA & NA & NA \\
\hline
\end{tabular}

Std. $=$ Streptomycin; $\mathrm{Ctrl}=N, N$-dimethylformamide $(\mathrm{DMF})$ in water $(25 \% \mathrm{v} / \mathrm{v}) ; \mathrm{NA}=$ Not active.

In the last step different arylidineamino analogues $\mathbf{6} \mathbf{a}-\mathbf{k}$ and $\mathbf{7 a}-\mathbf{k}$ were prepared by condensation of $\mathbf{5 a}$ and $\mathbf{5 b}$ with differently substituted aromatic aldehydes following some reported protocols. ${ }^{5,7,8,14)}$ The IR spectra of compound $\mathbf{6 a}-\mathbf{k}$ and $7 \mathbf{a}-\mathbf{k}$ showed characteristic signals of $\mathrm{C}=\mathrm{O}$ stretching and $\mathrm{C}=\mathrm{N}$ stretching (-imine). The loss of strong $\mathrm{N}-\mathrm{H}$ stretching signals of $3-\mathrm{NH}_{2}$ group was noticeable which revealed the formation of imine. The ${ }^{1} \mathrm{H}-\mathrm{NMR}$ spectra for compounds $\mathbf{6} \mathbf{a}-\mathbf{k}$ showed characteristic singlet at $\delta=9.4-10.2 \mathrm{ppm}$ could be assignable for single proton of imine $(-\mathrm{N}=\mathrm{CH})$ and another sharp singlet at $\delta=8.2-8.3 \mathrm{ppm}$ could be assignable to single proton $(2-\mathrm{H})$ of pyrimidinone ring. Compounds $7 \mathbf{a}-\mathbf{k}$ showed singlet at $\delta=9.2-10.2 \mathrm{ppm}$ could be assignable for single proton of imine $(-\mathrm{N}=\mathrm{CH})$ and another singlet at $\delta=2.59-2.63 \mathrm{ppm}$ could be assignable for methyl $\left(2-\mathrm{CH}_{3}\right)$ protons of pyrimidinone ring. The mass spectra (Electron Spray Ionization (ESI) and Electron Impact (EI) mode) showed the molecular ion $\left(\mathrm{M}^{+}, \mathrm{M}^{+}+1\right.$, $\left.\mathrm{M}^{+}+2\right)$ peaks for all the compounds. The halogenated compounds showed the isotopic peaks $\left(\mathrm{M}^{+}+1\right.$ and $\left.\mathrm{M}^{+}+2\right)$, which further confirms the presence of chlorine $(\mathrm{Cl})$ as a substituent, in compounds $\mathbf{6 b}, \mathbf{6 k}, \mathbf{7 b}$ and $\mathbf{7 k}$. The physical data of all the final compounds was shown in Table 1 .

Antibacterial Activity All the newly synthesized compounds $\mathbf{6 a}-\mathbf{k}$ and $\mathbf{7 a}-\mathbf{k}$ were assessed for their in vitro antibacterial activity against S. aureus (MTCC-96), B. subtilis (MTCC-441), E. coli (MTCC-443) and K. pneumoniae
(MTCC-109) using streptomycin as a reference. Broth micro dilution method $^{15,16)}$ was employed for determination of minimum inhibitory concentration (MIC) for all test compounds. The MIC $(\mu \mathrm{M})$ data of all the compounds were tabulated in Table 2.

Among all the synthesized compounds, 6b, 6c, 6d, 6i, $\mathbf{6 k}, \mathbf{7 b}, \mathbf{7 c}, \mathbf{7 d}$ and $\mathbf{7 k}$ exhibited good activity with MIC in the range of $11-24 \mu \mathrm{g} / \mathrm{mL}$ against $E$. coli and rest of the compounds showed moderate to less activity. The structure activity relationship reveals that presence of thieno(2,3- $d$ )pyrimidine-4-one ring with 3 -arylidineamino side chain skeleton is crucial for biological activity. In general, the arylidineamino side chain bearing substituted phenyl and heterocyclic groups showed more activity over unsubstituted analogues. Phenyl ring substituted with electron withdrawing groups such as chloro (4-Cl: $\mathbf{6 b}, \mathbf{7 b}$; 2,6-dichloro: $\mathbf{6 k}, \mathbf{7 k}$ ), flouro (4-F: $\mathbf{6 c}$, 7c) (excepting 4-methoxy: 6e, 7e) and also with thiophene (6i, 7i) system exhibited better activity when compared to electron donating groups such as hydroxyl (4-OH: 6f, 7f), 3, 4, 6-trimethoxyl $(\mathbf{6 g}, \mathbf{7 g})$. However nitro $\left(2-\mathrm{NO}_{2}\right)$ containing compounds $(\mathbf{6 h}, \mathbf{7 h})$ showed less activity. Compounds possessing 2,6-dichloro $(\mathbf{6 k}, \mathbf{7 k})$ substitution on phenyl ring exhibited potent activity on all the test organisms (Gram-positive and Gram-negative bacteria) used. Variations in the phenyl substitution might have altered the lipophilic character of molecules which is an important feature for permeability across the 
Table 3. Antimycobacterial Activity (in Vitro) of Test Compounds

\begin{tabular}{|c|c|c|c|c|c|c|}
\hline \multirow{3}{*}{ Comp. Code } & \multirow{3}{*}{$\mathrm{R}$} & \multirow{3}{*}{$\mathrm{R}^{1}$} & \multicolumn{4}{|c|}{$\operatorname{MIC}(\mu \mathrm{M})$} \\
\hline & & & \multicolumn{2}{|c|}{ MTB H37Rv } & \multicolumn{2}{|c|}{ Clinical sample of MTB } \\
\hline & & & $14 d$ & $21 \mathrm{~d}$ & $14 d$ & $21 \mathrm{~d}$ \\
\hline $6 \mathbf{b}$ & $\mathrm{H}$ & $4-\mathrm{ClC}_{6} \mathrm{H}_{4}$ & 46 & 46 & 46 & 46 \\
\hline $6 c$ & $\mathrm{H}$ & $4-\mathrm{FC}_{6} \mathrm{H}_{4}$ & 88 & 88 & 88 & 88 \\
\hline 6d & $\mathrm{H}$ & $4-\mathrm{CNC}_{6} \mathrm{H}_{4}$ & 180 & 180 & 180 & 180 \\
\hline $6 \mathrm{k}$ & $\mathrm{H}$ & $2,6-\mathrm{Cl}_{2} \mathrm{C}_{6} \mathrm{H}_{3}$ & 22 & 22 & 22 & 22 \\
\hline $7 \mathbf{b}$ & $\mathrm{CH}_{3}$ & $4-\mathrm{ClC}_{6} \mathrm{H}_{4}$ & 24 & 24 & 24 & 24 \\
\hline $7 c$ & $\mathrm{CH}_{3}$ & $4-\mathrm{FC}_{6} \mathrm{H}_{4}$ & 25 & 25 & 25 & 25 \\
\hline $7 d$ & $\mathrm{CH}_{3}$ & $4-\mathrm{CNC}_{6} \mathrm{H}_{4}$ & 22 & 22 & 22 & 22 \\
\hline $7 e$ & $\mathrm{CH}_{3}$ & $4-\mathrm{OCH}_{3} \mathrm{C}_{6} \mathrm{H}_{4}$ & 84 & 84 & 84 & 84 \\
\hline $7 \mathbf{i}$ & $\mathrm{CH}_{3}$ & Thiophene-2-yl & 98 & 98 & 98 & 98 \\
\hline $7 \mathbf{k}$ & $\mathrm{CH}_{3}$ & $2,6-\mathrm{Cl}_{2} \mathrm{C}_{6} \mathrm{H}_{3}$ & 11 & 11 & 11 & 11 \\
\hline $\mathrm{Std}^{1}$ & - & - & 0.1 & 0.1 & 4 & 4 \\
\hline $\mathrm{Std}^{2}$ & - & - & 2 & 2 & 2 & 2 \\
\hline $\mathrm{Std}^{3}$ & - & - & 4 & 4 & 4 & 4 \\
\hline $\mathrm{Std}^{4}$ & - & - & 0.09 & 0.09 & 2 & 2 \\
\hline Ctrl & - & - & NA & NA & NA & NA \\
\hline
\end{tabular}

$\mathrm{Std}^{1}=\mathrm{INH} ; \mathrm{Std}^{2}=$ Streptomycin; $\mathrm{Std}^{3}=$ Ethambutol; $\mathrm{Std}^{4}=$ Rifampicin; $\mathrm{Ctrl}=\mathrm{DMF}$ in water $(25 \% \mathrm{v} / \mathrm{v}) ; \mathrm{NA}=$ Not active.

Table 4. H-Bond Interactions of Biologically Active Ligands $\mathbf{6 k}, \mathbf{7 d}$ and $\mathbf{7 k}$

\begin{tabular}{|c|c|c|c|c|c|}
\hline Comp code & Residue & Atom ID & PDB atom name & Ligand name & Distance \\
\hline \multirow[t]{3}{*}{$6 \mathbf{k}$} & Gly 158 & 1163 & $N(d)$ & $\mathrm{O}(\mathrm{a})$ & 2.93 \\
\hline & Val 187 & 1397 & $N(d)$ & $\mathrm{N}(\mathrm{a})$ & 2.70 \\
\hline & Thr 186 & 1386 & $O(d+a)$ & $\mathrm{N}(\mathrm{a}+\mathrm{d})$ & 3.14 \\
\hline \multirow[t]{2}{*}{$7 d$} & Gly 158 & 1163 & $\mathrm{~N}(\mathrm{~d})$ & $\mathrm{O}(\mathrm{a})$ & 1.65 \\
\hline & Val 187 & 1397 & $N(d)$ & $\mathrm{N}(\mathrm{a})$ & 3.09 \\
\hline \multirow[t]{2}{*}{$7 \mathbf{k}$} & Gly 158 & 1163 & $N(d)$ & $\mathrm{O}(\mathrm{a})$ & 2.60 \\
\hline & Val 187 & 1397 & $N(d)$ & N (a) & 3.11 \\
\hline
\end{tabular}

bacterial cell membrane. The 4-hydroxyl (activating group) substituted compounds (6f and 7f) were found to be less potent might be due to their poor lipophilicity. On overall assessment most of the compounds showed activity against $E$. coli (Gram-negative bacteria). Methyl substitution at 2nd position of pyrimidine ring relatively enhanced the biological activity.

Antimycobacterial Activity Few compounds randomly selected for antimycobacterial studies by considering the preliminary antibacterial activity data. The MTB H37Rv and an INH-resistant clinical sample were taken as reference and test organisms, respectively. The MIC was determined on Middlebrook 7H9 medium supplemented with OADC using broth micro dilution method with the help of four well known drugs (INH, Streptomycin, Rifampicin and Ethambutol) as reference. ${ }^{17}$ The test samples were prepared by serial dilution method in different strengths in DMF in water $(25 \% \mathrm{v} / \mathrm{v})$ as diluent. Among all the tested compounds 7k, bearing 2, 6-dichloro substitution on arylidineamino side chain showed greater activity with MIC-11 $\mu \mathrm{M}$ against MTB H37Rv and also clinical sample (INH-resistant). Other compounds bearing 2,6-dichloro (6k), 4-Cl (7b), 4-F (7c) and 4-CN (7d) showed activity in the MIC range of $22-25 \mu \mathrm{M}$ on both the strains. The additional chloro $(\mathrm{Cl})$ group at 2 nd position of phenyl ring in
$7 \mathbf{k}$, 6k instead monochloro (4-Cl) substitution in $\mathbf{6 b}, \mathbf{7 b}$ enhanced the biological activity. Compounds, $\mathbf{6 c}, \mathbf{6 d}, 7 \mathbf{7}$ and $7 \mathbf{i}$ exhibited poor in potency and their MIC range was observed at $\geq 46 \mu \mathrm{M}$. The antimycobacterial activity (MIC in $\mu \mathrm{M}$ ) data is tabulated in Table 3.

Molecular Modeling The molecular docking studies were performed on target protein MTB-PS, which has been proven to be valid drug target for rational design of new analogues for TB by several reports. ${ }^{18,19)}$ The crystal structure of MTB-PS was retrieved from protein data bank ((PDB: 3IVX) (http://www.rcsb.org/pdb/explore.do?structure Id=3ivx). Ligands possessing 4-flouro (6c), 4-hydroxy (6f), 2-nitro (6h), 4-methoxy (7e) and 2,4-dichloro (6k, 7k) substitution on phenyl ring of arylidineamino side chain showed best docking scores, i.e., $-118.43,-118.42,-122.87,-121.03,-120.68$ and -115.63 , respectively.

The carbonyl $(\mathrm{C}=\mathrm{O}, \mathrm{H}$-bond acceptor) group at 4 th position in pyrimidine ring showed strong hydrogen bond interaction with Gly 158 (H-bond donor) amino acid residue in all $(\mathbf{6 a}-\mathbf{k}$ and $7 \mathbf{a}-\mathbf{k})$ the ligands. Another H-bond interaction was observed at nitrogen (7-N) atom of the 5,6,7,8-tetrahydrothieno[2,3- $d]$ pyridine ring with Val 187 amino acid residue (Table 4). 


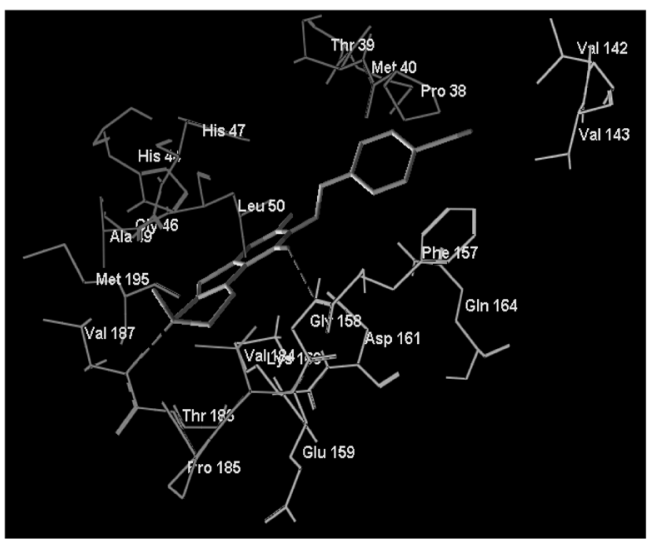

A

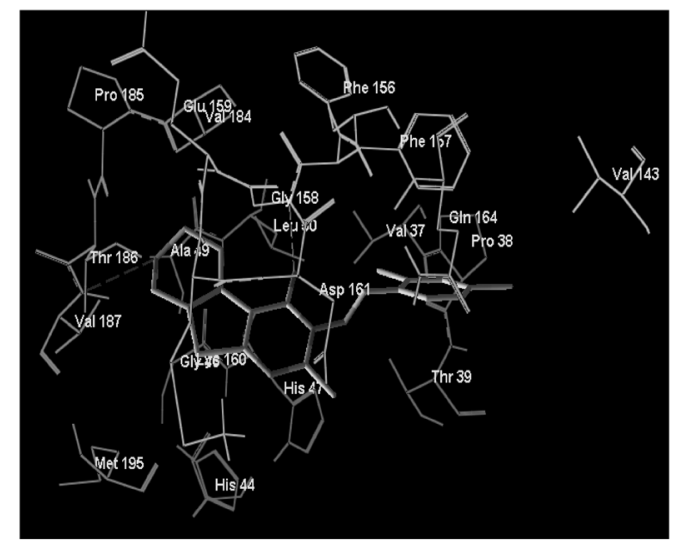

B

Fig. 2. Snapshots of the Typical Binding Interactions of Ligands $7 \mathbf{b}$ (A) and 7k (B) with Active Site of MTB-PS, Hydrogen Bond Interactions of $\mathrm{C}=\mathrm{O}$ Group with Residue of Gly 158 and Nitrogen (7-N) with Val 187

Additionally, the steric interactions observed for all the molecules with amino acid residues such as Leu 50, Val 184, Pro 185, Gln164 and Pro 38. All these molecules 6a-k and $7 \mathbf{a}-\mathbf{k}$ lack additional $\pi-\pi$ stacking and van der Waals interactions due to presence of $N$-methyl group at 7th position, hence they showed less potency compared to $N$-benzyl analogues. ${ }^{5}$ The binding mode and orientation pattern at active site were analyzed for all molecules. The docking poses of the experimentally more potent molecules $\mathbf{7 b}$ and $7 \mathbf{k}$ were showed in Fig. 2.

\section{Conclusion}

In conclusion this study deals with the design and synthesis of novel analogues of 7-methyl-5,6,7,8tetrahydropyrido $\left[4^{\prime}, 3^{\prime}: 4,5\right]$ thieno $[2,3-d]$ pyrimidin-4(3H)-ones. Among all the compounds 6a, 6b, 6c, 6d, 6k, 7b, 7c, 7d, 7e and $7 \mathbf{k}$ showed promising antibacterial activity against $E$. coli in the MIC range 10-24 $\mu \mathrm{M}$ and compounds $6 \mathbf{k}, 7 \mathbf{b}, 7 \mathbf{c}, 7 \mathbf{d}$ and $\mathbf{7 k}$ further showed antimycobacterial activity in the MIC range $10-25 \mu \mathrm{M}$ against $\mathrm{MTB} \mathrm{H} 37 \mathrm{Rv}$ and an INH-resistant clinical sample. Among these compound $7 \mathbf{k}$ was found to be more potent (MIC-11 $\mu \mathrm{M}$ ). Further the molecular docking studies helped in knowing the binding modes of core structure with active sites and the docking scores obtained were correlated with the MIC values $(\mu \mathrm{M})$ of most of the compounds. Further investigations are in progress on enzyme inhibitory activity, cytotoxicity and pharmacokinetic properties to validate these results.

\section{Experimental}

Chemistry Melting points of all the compounds were determined in open capillaries on melting point apparatus (Biotechniques India-BTI-34), and are uncorrected. Purity and homogeneity was verified by pre-coated TLC plates (E. Merck silica gel $60 \mathrm{~F}_{254}$ ). IR spectra were recorded using $\mathrm{KBr}$ pellet method on Bruker spectrophotometer and Perkin-Elmer FTIR 240-C ( $v_{\max }$ in $\left.\mathrm{cm}^{-1}\right)$. The ${ }^{1} \mathrm{H}-\mathrm{NMR}$ and ${ }^{13} \mathrm{C}-\mathrm{NMR}$ was recorded on a Bruker spectrometer $500 \mathrm{MHz}$ and $400 \mathrm{MHz}$ respectively using tetramethylsilane (TMS) as internal standard, Central Instrumentation Laboratory, Indian Institute of Chemical Technology, Hyderabad, India. The chemical shifts $(\delta)$ are reported in part per million $(\mathrm{ppm})$ relative to TMS using $\mathrm{CDCl}_{3}$ as solvent. Signal multiplicities are represented by s (singlet), d (doublet), t (triplet), q (quartet), br s (broad singlet), dd (double doublet) and m (multiplet). MS were recorded on ESI and EI mode using QSTARXL hybrid MS/MS system (Applied Bio-systems, U.S.A.), Central Instrumentation Laboratory, Indian Institute of Chemical Technology, Hyderabad, India. Elemental analysis was carried out using vario MICRO CUBE Elementar (2mgChem80s method), Kakatiya University, Warangal. All the chemicals used in the synthesis were procured from Aldrich Company Ltd. (Bengaluru, India) and Himedia Chemicals (Mumbai, India). All the solvents used were purchased from SD Fine Chemicals Ltd. (Mumbai, India) and were employed without further purification.

Ethyl-2-amino-6-methyl-4,5,6,7-tetrahydrothieno[2,3-c]pyridine-3-carboxylate (3) $N$-Methyl-4-piperidone (1) (5 g, $26.42 \mathrm{mmol})$, ethyl cyanoacetate (2) $(3.09 \mathrm{~mL}, 29.06 \mathrm{mmol})$ and sulphur $(1.02 \mathrm{~g}, 31.70 \mathrm{mmol})$ were suspended in ethanol $(55 \mathrm{~mL})$. Morpholine $(4.62 \mathrm{~mL}, 52.84 \mathrm{mmol})$ was added and the mixture was heated under reflux gently with stirring for $2 \mathrm{~h}$. The cooled solution was diluted with water and extracted with dichloromethane $(3 \times 50 \mathrm{~mL})$. The combined organic layers were washed with water, then brine, dried $\left(\mathrm{MgSO}_{4}\right)$, filtered and concentrated. The resultant residue was triturated with hot methanol $(20 \mathrm{~mL})$ and washed with ice cold methanol to afford the desired product as an off white powder.

Yield, $7.1 \mathrm{~g} \mathrm{(85 \% ).} \mathrm{mp} 110-111^{\circ} \mathrm{C}$. IR (KBr) $\mathrm{cm}^{-1}$ : 3344, $3254(\mathrm{~N}-\mathrm{H}$, str $), 2986,2878(\mathrm{C}-\mathrm{H}$, str $), 1685(\mathrm{C}=\mathrm{O}$, str $)$. ${ }^{1} \mathrm{H}-\mathrm{NMR}\left(\mathrm{CDCl}_{3}\right) \delta(\mathrm{ppm}): 6.03\left(2 \mathrm{H}, \mathrm{brs}, 2-\mathrm{NH}_{2}\right), 4.27(2 \mathrm{H}, \mathrm{q}$, $J=7.2 \mathrm{~Hz}, \mathrm{CH}_{2}$ of carboxylate), $3.39\left(2 \mathrm{H}, \mathrm{s}, 7-\mathrm{CH}_{2}\right), 2.85(2 \mathrm{H}$, t, $\left.J=5.7 \mathrm{~Hz}, 5-\mathrm{CH}_{2}\right), 2.68\left(2 \mathrm{H}, \mathrm{t}, J=5.8 \mathrm{~Hz}, 4-\mathrm{CH}_{2}\right), 2.45(3 \mathrm{H}$, $\left.\mathrm{s}, 7-\mathrm{NCH}_{3}\right), 1.34\left(3 \mathrm{H}, \mathrm{t}, J=7.2 \mathrm{~Hz},-\mathrm{CH}_{3}\right.$ of carboxylate). ESIMS (m/z;\%): $241\left(\mathrm{M}^{+}+1 ; 100\right)$.

3-Amino-7-methyl-5,6,7,8-tetrahydropyrido $\left[4^{\prime}, 3^{\prime}: 4,5\right]-$ thieno[2,3- $d]$ pyrimidin-4(3H)-one (5a) A solution of 3 $(1.10 \mathrm{~g}, 57 \mathrm{mmol})$ in triethylorthoformate $(5 \mathrm{~mL})$ was heated under reflux for 2-4h. Excess triethylorthoformate was removed in vacuo. The residue was treated with ethyl acetate in hexane $(20 \% \mathrm{v} / \mathrm{v})$ and dried to obtain light brown oily product (4a). It was used directly in next step without purification. A mixture of $4 \mathbf{a}$ and hydrazine hydrate $(1 \mathrm{~mL})$ in $10 \mathrm{~mL}$ of absolute ethanol was stirred at room temperature for $1-2 \mathrm{~h}$. The separated fine solid was filtered, washed with ethanol and purified by recrystallization from ethanol to afford analytically pure pale yellow granules. 
Yield, $0.76 \mathrm{~g}(71 \%) . \mathrm{mp} 194-196^{\circ} \mathrm{C}$. IR $(\mathrm{KBr}) \mathrm{cm}^{-1}: 3450$, $3300(\mathrm{~N}-\mathrm{H}$, str $), 2910(\mathrm{C}-\mathrm{H}$, str $), 1670(\mathrm{C}=\mathrm{O}$, str $) .{ }^{1} \mathrm{H}-\mathrm{NMR}$ $\left(\mathrm{CDCl}_{3}\right) \delta$ (ppm): $2.50\left(3 \mathrm{H}, \mathrm{s}, 7-\mathrm{NCH}_{3}\right), 2.80(2 \mathrm{H}, \mathrm{t}, J=6 \mathrm{~Hz}$, $\left.5-\mathrm{CH}_{2}\right), 3.20\left(2 \mathrm{H}, \mathrm{t}, J=6 \mathrm{~Hz}, 6-\mathrm{CH}_{2}\right), 3.67\left(2 \mathrm{H}, \mathrm{s}, 8-\mathrm{CH}_{2}\right), 5.13$ $\left(2 \mathrm{H}\right.$, brs, 3- $\left.\mathrm{NH}_{2}\right), 8.20(1 \mathrm{H}, \mathrm{s}, 2-\mathrm{H}$ pyrimidinone). ESI-MS $(\mathrm{m} / \mathrm{z} ; \%): 236\left(\mathrm{M}^{+}+1 ; 100\right)$.

3-Amino-2,7-dimethyl-5,6,7,8-tetrahydropyrido $\left[4^{\prime}, 3^{\prime}: 4,5\right]-$ thieno[2,3-d]pyrimidin-4(3H)-one (5b) A solution of 3 $(1.10 \mathrm{~g}, 57 \mathrm{mmol})$ in triethylorthoacetate $(5 \mathrm{~mL})$ was heated under reflux for 2-4h. Excess triethyorthoacetate was removed in vacuo. The residue was treated with ethyl acetate in hexane $(20 \% \mathrm{v} / \mathrm{v})$ and dried to obtain light brown oily product (4b). It was used directly in next step without purification. A mixture of $\mathbf{4 b}$ and hydrazine hydrate $(1 \mathrm{~mL})$ in $10 \mathrm{~mL}$ of absolute ethanol was stirred at room temperature for $1-2 \mathrm{~h}$. The separated fine solid was filtered, washed with ethanol and purified by recrystallization from ethanol to afford analytically pure pale yellow granules.

Yield, $0.84 \mathrm{~g}(74 \%) . \mathrm{mp} 200-202^{\circ} \mathrm{C}$. IR $(\mathrm{KBr}) \mathrm{cm}^{-1}: 3450$, $3300(\mathrm{~N}-\mathrm{H}, s t r), 2910(\mathrm{C}-\mathrm{H}, s t r), 1670(\mathrm{C}=\mathrm{O}$, str $) .{ }^{1} \mathrm{H}-\mathrm{NMR}$ $\left(\mathrm{CDCl}_{3}\right) \delta(\mathrm{ppm}): 2.20\left(3 \mathrm{H}, \mathrm{s}, 2-\mathrm{CH}_{3}\right.$ of pyrimidinone), 2.50 $\left(3 \mathrm{H}, \mathrm{s}, 7-\mathrm{NCH}_{3}\right), 2.80\left(2 \mathrm{H}, \mathrm{t}, J=5.82 \mathrm{~Hz}, 5-\mathrm{CH}_{2}\right), 3.20(2 \mathrm{H}$, t, $\left.J=5.73 \mathrm{~Hz}, 6-\mathrm{CH}_{2}\right), 3.67\left(2 \mathrm{H}, \mathrm{s}, 8-\mathrm{CH}_{2}\right), 5.13(2 \mathrm{H}$, brs, $\left.3-\mathrm{NH}_{2}\right)$. ESI-MS ( $\left./ \mathrm{z} ; \%\right): 250\left(\mathrm{M}^{+}+1 ; 85\right)$.

7-Methyl-3-(substituted-aryledineamino)-5,6,7,8-tetrahydropyrido $\left[4^{\prime}, 3^{\prime}: 4,5\right]$ thieno $[2,3-d]$ pyrimidin-4(3H)-one (6a-k)

General Method

A mixture of $5 \mathbf{a}(0.001 \mathrm{M})$ and appropriate aldehyde $(0.001 \mathrm{M})$ in catalytic amount of glacial acetic acid in $10 \mathrm{~mL}$ of absolute ethanol was heated under reflux for $2-6 \mathrm{~h}$. On cooling, the separated solid was filtered, washed with cold ethanol and recrystallized from acetic acid: ethanol to afford desired product.

3-(Benzylideneamino)-7-methyl-5,6,7,8-tetrahydropyrido $\left[4^{\prime}, 3^{\prime}: 4,5\right]$ thieno[2,3-d]pyrimidin-4 $(3 H)$-one (6a) [El-Kashef et al. ${ }^{11)}$

3-((4-Chlorobenzylidene)amino)-7-methyl-5,6,7,8-tetrahydropyrido $\left[4^{\prime}, 3^{\prime}: 4,5\right]$ thieno[2,3-d]pyrimidin-4(3H)-one (6b) [ElKashef et al.]. ${ }^{11)}$

3 -((4-Fluorobenzylidene) amino) -7-methyl-5, 6, 7, 8tetrahydropyrido $\left[4^{\prime}, 3^{\prime}: 4,5\right]$ thieno[2,3-d]pyrimidin-4(3H)-one (6c)

Yield, $0.22 \mathrm{~g}(64 \%) . \mathrm{mp} 180-182^{\circ} \mathrm{C}$. IR (KBr) $\mathrm{cm}^{-1}$ : 3069, 3031 (aromatic C-H, str), 2919 (aliphatic C-H, str), 1672 $(\mathrm{C}=\mathrm{O}$, str $), 1601(\mathrm{C}=\mathrm{N}$, str $) .{ }^{1} \mathrm{H}-\mathrm{NMR}\left(\mathrm{CDCl}_{3}\right) \delta$ (ppm): 2.59 $\left(3 \mathrm{H}, \mathrm{s}, 7-\mathrm{CH}_{3}\right), 2.79\left(2 \mathrm{H}, \mathrm{t}, J=5.88 \mathrm{~Hz}, 5-\mathrm{CH}_{2}\right), 3.18(2 \mathrm{H}, \mathrm{t}$, $\left.J=5.94 \mathrm{~Hz}, 6-\mathrm{CH}_{2}\right), 3.67\left(2 \mathrm{H}, \mathrm{s}, 8-\mathrm{CH}_{2}\right), 7.18(2 \mathrm{H}, \mathrm{t}, J=8.62 \mathrm{~Hz}$, $\left.3^{\prime}, 5^{\prime}-\mathrm{Ar}-\mathrm{H}\right), 7.85$ (2H, dd, J=5.4, 5.4 Hz, 2',6'-Ar-H), $8.24(1 \mathrm{H}$, $\mathrm{s}, 2-\mathrm{H}$ of pyrimidinone), $9.53(1 \mathrm{H}, \mathrm{s}, \mathrm{N}=\mathrm{CH}) .{ }^{13} \mathrm{C}-\mathrm{NMR}$ $\left(\mathrm{CDCl}_{3}\right) \delta(\mathrm{ppm}): 26.12,45.48,51.89,53.76,116.34-116.34(d)$, $122.92,129.31-129.34(d), 130.13,130.71-130.80(d), 132.07$, 145.57, 156.37, 160.86, 162.43, 164.01, 166.53. ESI-MS $(\mathrm{m} / \mathrm{z}$; \%): $343\left(\mathrm{M}^{+}+1 ; 100\right)$. Anal. Calcd for $\mathrm{C}_{17} \mathrm{H}_{15} \mathrm{FN}_{4} \mathrm{OS}$ : C, 59.63; H, 4.42; N, 16.36. Found: C, 58.92; H, 4.46; N, 16.88.

4-(((7-Methyl-4-oxo-5,6,7,8-tetrahydropyrido [4',3':4,5]thieno[2,3-d]pyrimidin-3(4H)-yl)imi no)methyl)benzonitrile (6d)

Yield, $0.23 \mathrm{~g}(67 \%) . \mathrm{mp} 236-238^{\circ} \mathrm{C}$. IR $(\mathrm{KBr}) \mathrm{cm}^{-1}: 3099$ (aromatic C-H, str), 2955 (aliphatic C-H, str), 2229 (CN, str), $1674(\mathrm{C}=\mathrm{O}$, str $), 1545(\mathrm{C}=\mathrm{N}$, str $) .{ }^{1} \mathrm{H}-\mathrm{NMR}\left(\mathrm{CDCl}_{3}\right) \delta(\mathrm{ppm})$ : $2.56\left(3 \mathrm{H}, \mathrm{s}, 7-\mathrm{NCH}_{3}\right), 2.79\left(2 \mathrm{H}, \mathrm{t}, J=5.12 \mathrm{~Hz}, 5-\mathrm{CH}_{2}\right), 3.18$ $\left(2 \mathrm{H}, \mathrm{t}, J=5.22 \mathrm{~Hz}, 6-\mathrm{CH}_{2}\right), 3.66\left(2 \mathrm{H}, \mathrm{s}, 8-\mathrm{CH}_{2}\right), 7.78(2 \mathrm{H}, \mathrm{d}$, $\left.J=8.86 \mathrm{~Hz}, 33^{\prime}, 5^{\prime}-\mathrm{Ar}-\mathrm{H}\right), 7.94\left(2 \mathrm{H}, \mathrm{d}, J=8.84 \mathrm{~Hz}, 2^{\prime}, 6^{\prime}-\mathrm{Ar}-\mathrm{H}\right)$, $8.28(1 \mathrm{H}, \mathrm{s}, 2-\mathrm{H}$ of pyrimidinone), $9.92(1 \mathrm{H}, \mathrm{s}, \mathrm{N}=\mathrm{CH})$. ${ }^{13} \mathrm{C}-\mathrm{NMR}\left(\mathrm{CDCl}_{3}\right) \delta$ (ppm): 26.12, 45.47, 51.84, 53.73, 115.24, $118.08,122.87,128.76,130.23,132.51,132.61,137.44,146.02$, 156.76, 159.70, 160.69. ESI-MS ( $m / z ; \%)$ : $350\left(\mathrm{M}^{+}+1 ; 100\right)$. Anal. Calcd for $\mathrm{C}_{18} \mathrm{H}_{15} \mathrm{~N}_{5} \mathrm{OS}$ : C, 61.87; H, 4.33; N, 20.04. Found: C, 61.58; H, 4.76; N, 19.82.

3-((4-Methoxybenzylidene)amino)-7-methyl-5,6,7,8-tetrahydropyrido $\left[4^{\prime}, 3^{\prime}: 4,5\right]$ thieno $[2,3-d]$ pyrimidin-4(3H)-one (6e) [El-Kashef et al.]. ${ }^{11)}$

3-((4-Hydroxybenzylidene)amino)-7-methyl-5,6,7,8-tetrahydropyrido $\left[4^{\prime}, 3^{\prime}: 4,5\right]$ thieno $[2,3-d]$ pyrimidin-4(3H)-one [El-Kashef et al.]. ${ }^{11)}$

7-Methyl-3-((3,4,5-trimethoxybenzylidene)amino)-5,6,7,8tetrahydropyrido $\left[4^{\prime}, 3^{\prime}: 4,5\right]$ thieno[2,3-d]pyrimidin-4(3H)-one (6g)

Yield, $0.28 \mathrm{~g}(67 \%) . \mathrm{mp} 192-194^{\circ} \mathrm{C}$. IR $(\mathrm{KBr}) \mathrm{cm}^{-1}: 3059$ (aromatic C-H, str), 2937, 2776 (aliphatic $\mathrm{C}-\mathrm{H}$, str), 1672 $(\mathrm{C}=\mathrm{O}$, str $), 1576(\mathrm{C}=\mathrm{N}$, str $) .{ }^{1} \mathrm{H}-\mathrm{NMR}\left(\mathrm{CDCl}_{3}\right) \delta(\mathrm{ppm}): 2.52$ $\left(3 \mathrm{H}, \mathrm{s}, 7-\mathrm{NCH}_{3}\right), 2.81\left(2 \mathrm{H}, \mathrm{t}, J=5.86 \mathrm{~Hz}, 5-\mathrm{CH}_{2}\right), 3.22(2 \mathrm{H}, \mathrm{t}$, $\left.J=5.89 \mathrm{~Hz}, 6-\mathrm{CH}_{2}\right), 3.69\left(2 \mathrm{H}, \mathrm{s}, 8-\mathrm{CH}_{2}\right), 3.94\left(6 \mathrm{H}, \mathrm{s}, 3^{\prime}, 5^{\prime}-\mathrm{Ar}-\right.$ $\left.\mathrm{OCH}_{3}\right), 3.96\left(3 \mathrm{H}, \mathrm{s}, 4^{\prime}-\mathrm{Ar}-\mathrm{OCH}_{3}\right), 7.12\left(2 \mathrm{H}, \mathrm{s}, 2^{\prime}, 6^{\prime}-\mathrm{Ar}-\mathrm{H}\right), 8.26$ $(1 \mathrm{H}, \mathrm{s}, 2-\mathrm{H}$ of pyrimidinone), $9.44(1 \mathrm{H}, \mathrm{s}, \mathrm{N}=\mathrm{CH})$. ESI-MS $(m / z ; \%): 415\left(\mathrm{M}^{+}+1 ; 100\right)$. Anal. Calcd for $\mathrm{C}_{20} \mathrm{H}_{22} \mathrm{~N}_{4} \mathrm{O}_{4} \mathrm{~S}: \mathrm{C}$, 57.96; H, 5.35; N, 13.52. Found: C, 57.92; H, 5.46; N, 13.68.

7-Methyl-3-((2-nitrobenzylidene)amino)-5,6,7,8-tetrahydropyrido $\left[4^{\prime}, 3^{\prime}: 4,5\right]$ thieno[2,3- $\left.d\right]$ pyrimidin-4(3H)-one (6h)

Yield, $0.27 \mathrm{~g}(72 \%)$. mp $159-161^{\circ} \mathrm{C}$. IR $(\mathrm{KBr}) \mathrm{cm}^{-1}: 3019$ (aromatic $\mathrm{C}-\mathrm{H}$, str), 2932, 2774 (aliphatic $\mathrm{C}-\mathrm{H}$, str), 1686 $(\mathrm{C}=\mathrm{O}$, str $), 1524(\mathrm{C}=\mathrm{N}$, str $) .{ }^{1} \mathrm{H}-\mathrm{NMR}\left(\mathrm{CDCl}_{3}\right) \delta(\mathrm{ppm})$ : $2.51\left(3 \mathrm{H}, \mathrm{s}, 7-\mathrm{NCH}_{3}\right), 2.79\left(2 \mathrm{H}, \mathrm{t}, J=5.88 \mathrm{~Hz}, 5-\mathrm{CH}_{2}\right), 3.18$ $\left(2 \mathrm{H}, \mathrm{t}, J=5.88 \mathrm{~Hz}, 6-\mathrm{CH}_{2}\right), 3.67\left(2 \mathrm{H}, \mathrm{s}, 8-\mathrm{CH}_{2}\right), 7.72(1 \mathrm{H}, \mathrm{dt}$, $\left.J=8.02 \mathrm{~Hz}, 4^{\prime}-\mathrm{Ar}-\mathrm{H}\right), 7.78\left(1 \mathrm{H}, \mathrm{dt}, J=8.02 \mathrm{~Hz}, 5^{\prime}-\mathrm{Ar}-\mathrm{H}\right), 8.18$ $\left(2 \mathrm{H}, \mathrm{dd}, J=8.12,1.52 \mathrm{~Hz}, 3^{\prime}, 6^{\prime}-\mathrm{Ar}-\mathrm{H}\right), 8.28(1 \mathrm{H}, \mathrm{s}, 2-\mathrm{H}$ of pyrimidinone), $10.18(1 \mathrm{H}, \mathrm{s}, \mathrm{N}=\mathrm{CH}) .{ }^{13} \mathrm{C}-\mathrm{NMR}\left(\mathrm{CDCl}_{3}\right) \delta(\mathrm{ppm})$ : $26.04,45.43,51.84,53.72,122.94,124.86,128.49,129.42$, $130.36,131.97,132.28,133.73,145.57,148.86,156.20,159.57$, 160.75. ESI-MS $(\mathrm{m} / \mathrm{z} ; \%)$ : $370\left(\mathrm{M}^{+}+1 ; 100\right)$. Anal. Calcd for $\mathrm{C}_{17} \mathrm{H}_{15} \mathrm{~N}_{5} \mathrm{O}_{3} \mathrm{~S}$ : C, 55.27; H, 4.09; N, 18.96. Found: C, 55.42; H, 4.46; N, 18.88 .

7-Methyl-3-((thiophen-2-ylmethylene)amino) -5, 6,7,8tetrahydropyrido $\left[4^{\prime}, 3^{\prime}: 4,5\right]$ thieno $[2,3-d]$ pyrimidin-4(3H)-one (6i)

Yield, $0.22 \mathrm{~g}(66 \%) . \mathrm{mp} 120-122^{\circ} \mathrm{C}$. IR $(\mathrm{KBr}) \mathrm{cm}^{-1}$ : 3051 (aromatic C-H, str), 2938, 2785 (aliphatic C-H, str), 1683 $(\mathrm{C}=\mathrm{O}$, str $), 1581(\mathrm{C}=\mathrm{N}$, str $) .{ }^{1} \mathrm{H}-\mathrm{NMR}\left(\mathrm{CDCl}_{3}\right) \delta(\mathrm{ppm}): 2.51$ $\left(3 \mathrm{H}, \mathrm{s}, 7-\mathrm{NCH}_{3}\right), 2.81\left(2 \mathrm{H}, \mathrm{t}, J=5.88 \mathrm{~Hz}, 5-\mathrm{CH}_{2}\right), 3.19(2 \mathrm{H}, \mathrm{t}$, $\left.J=5.79 \mathrm{~Hz}, 6-\mathrm{CH}_{2}\right), 3.68\left(2 \mathrm{H}, \mathrm{s}, 8-\mathrm{CH}_{2}\right), 7.26(1 \mathrm{H}, \mathrm{dt}, J=5$, $1.12 \mathrm{~Hz}, 4^{\prime}-\mathrm{Ar}-\mathrm{H}$ of thiophene), $7.54(1 \mathrm{H}, \mathrm{dd}, J=3.88,1.53 \mathrm{~Hz}$, $3^{\prime}$-Ar-H of thiophene), $7.58\left(1 \mathrm{H}, \mathrm{dd}, J=5.01,3.12 \mathrm{~Hz}, 5^{\prime}-\mathrm{Ar}-\mathrm{H}\right.$ of thiophene), $8.25(1 \mathrm{H}, \mathrm{s}, 2-\mathrm{H}$ of pyrimidinone), $9.78(1 \mathrm{H}$, $\mathrm{s}, \mathrm{N}=\mathrm{CH}) .{ }^{13} \mathrm{C}-\mathrm{NMR}\left(\mathrm{CDCl}_{3}\right) \delta(\mathrm{ppm}): 25.80,49.87,51.64$, $62.01,112.54,118.74,127.36,128.44,129.14,130.28,137.96$, 146.90, 153.58, 155.08, 161.19. ESI-MS ( $m / z ; \%): 331\left(\mathrm{M}^{+}+1\right.$; 100). Anal. Calcd for $\mathrm{C}_{15} \mathrm{H}_{14} \mathrm{~N}_{4} \mathrm{OS}_{2}$ : C, 54.52; H, 4.27; N, 16.96. Found: C, 54.82; H, 4.46; N, 16.88 .

3-((Furan-2-ylmethylene)amino)-7-methyl-5,6,7,8-tetrahydropyrido $\left[4^{\prime}, 3^{\prime}: 4,5\right]$ thieno[2,3- $\left.d\right]$ pyrimidin-4(3H)-one $(\mathbf{6 j})$

Yield, $0.25 \mathrm{~g}(80 \%)$. mp $156-158^{\circ} \mathrm{C}$. IR (KBr) $\mathrm{cm}^{-1}: 3104$ 
(aromatic C-H, str), 2920, 2841 (aliphatic C-H, str), 1662 $(\mathrm{C}=\mathrm{O}$, str $), 1539(\mathrm{C}=\mathrm{N}$, str $) .{ }^{1} \mathrm{H}-\mathrm{NMR}\left(\mathrm{CDCl}_{3}\right) \delta(\mathrm{ppm}): 2.54$ $\left(3 \mathrm{H}, \mathrm{s}, 7-\mathrm{NCH}_{3}\right), 2.82\left(2 \mathrm{H}, \mathrm{t}, J=5.82 \mathrm{~Hz}, 5-\mathrm{CH}_{2}\right), 3.20(2 \mathrm{H}, \mathrm{t}$, $\left.J=5.83 \mathrm{~Hz}, 6-\mathrm{CH}_{2}\right), 3.68\left(2 \mathrm{H}, \mathrm{s}, 8-\mathrm{CH}_{2}\right), 6.58(1 \mathrm{H}, \mathrm{dd}, J=3.48$, $1.76 \mathrm{~Hz}, 4^{\prime}-\mathrm{Ar}-\mathrm{H}$ of furan), $7.02\left(1 \mathrm{H}, \mathrm{d}, J=3.22 \mathrm{~Hz}, 5^{\prime}-\mathrm{Ar}-\mathrm{H}\right.$ of furan), $7.69\left(1 \mathrm{H}, \mathrm{d}, J=1.55 \mathrm{~Hz}, 3^{\prime}-\mathrm{Ar}-\mathrm{H}\right.$ of furan $), 8.29(1 \mathrm{H}, \mathrm{s}$, $2-\mathrm{H}$ of pyrimidinone), $9.54(1 \mathrm{H}, \mathrm{s}, \mathrm{N}=\mathrm{CH})$. EI-MS $(\mathrm{m} / \mathrm{z} ; \%)$ : $314\left(\mathrm{M}^{+} ; 62\right), 315\left(\mathrm{M}^{+}+1 ; 12\right)$. Anal. Calcd for $\mathrm{C}_{15} \mathrm{H}_{14} \mathrm{~N}_{4} \mathrm{O}_{2} \mathrm{~S}$ : C, 57.31; H, 4.49; N, 17.82. Found: C, 57.72; H, 4.46; N, 16.18.

3-((2,4-Dichlorobenzylidene)amino)-7-methyl-5,6,7,8-tetrahydropyrido $\left[4^{\prime}, 3^{\prime}: 4,5\right]$ thieno[2,3- $\left.d\right]$ pyrimidin-4(3H)-one $(6 \mathbf{k})$

Yield, $0.32 \mathrm{~g}(82 \%)$. mp $190-192^{\circ} \mathrm{C}$. IR $(\mathrm{KBr}) \mathrm{cm}^{-1}$ : 3083 (aromatic C-H, str), 2938, 2783 (aliphatic C-H, str), 1681 $(\mathrm{C}=\mathrm{O}$, str $), 1582(\mathrm{C}=\mathrm{N}$, str $) .{ }^{1} \mathrm{H}-\mathrm{NMR}\left(\mathrm{CDCl}_{3}\right) \delta(\mathrm{ppm})$ : $2.50\left(3 \mathrm{H}, \mathrm{s}, 7-\mathrm{NCH}_{3}\right), 2.79\left(2 \mathrm{H}, \mathrm{t}, J=5.98 \mathrm{~Hz}, 5-\mathrm{CH}_{2}\right), 3.19$ $\left(2 \mathrm{H}, \mathrm{t}, J=5.56 \mathrm{~Hz}, 6-\mathrm{CH}_{2}\right), 3.71\left(2 \mathrm{H}, \mathrm{s}, 8-\mathrm{CH}_{2}\right), 7.34(1 \mathrm{H}, \mathrm{dd}$, $\left.J=1.6,2.5 \mathrm{~Hz}, 5^{\prime}-\mathrm{Ar}-\mathrm{H}\right), 7.47$ (1H, d, $\left.J=2 \mathrm{~Hz}, 3^{\prime}-\mathrm{Ar}-\mathrm{H}\right), 8.13$ $\left(1 \mathrm{H}, \mathrm{d}, J=8.2 \mathrm{~Hz}, 6^{\prime}-\mathrm{Ar}-\mathrm{H}\right), 8.23(1 \mathrm{H}, \mathrm{s}, 2-\mathrm{H}$ of pyrimidinone), $10.09(1 \mathrm{H}, \mathrm{s}, \mathrm{N}=\mathrm{CH}) .{ }^{13} \mathrm{C}-\mathrm{NMR}\left(\mathrm{CDCl}_{3}\right) \delta(\mathrm{ppm}): 26.14$, $45.44,51.84,53.73,122.93,127.74,128.45,129.60,129.98$, 130.30, 132.17, 136.80, 138.56, 145.80, 156.40, 158.37, 160.67. ESI-MS ( $m / z ; \%): 394\left(\mathrm{M}^{+}+2 ; 35\right), 392\left(\mathrm{M}^{+} ; 100\right)$. Anal. Calcd for $\mathrm{C}_{17} \mathrm{H}_{14} \mathrm{Cl} 2 \mathrm{~N}_{4} \mathrm{OS}$ : C, 51.92; H, 3.59; N, 14.25. Found: C, 51.72; H, 3.46; N, 14.48 .

2,7-Dimethyl-3-(substituted-aryledineamino)-5,6,7,8tetrahydropyrido $\left[4^{\prime}, 3^{\prime}: 4,5\right]$ thieno $[2,3-d]$ pyrimidin- $4(3 H)$ one $(7 \mathbf{a}-\mathbf{k})$

General Method

A mixture of $\mathbf{5 b}(0.001 \mathrm{M})$ and appropriate aldehyde $(0.001 \mathrm{M}))$ in catalytic amount of glacial acetic acid in $10 \mathrm{~mL}$ of absolute ethanol was heated under reflux for about 2-6h. On cooling, the separated solid was filtered, washed with cold ethanol and recrystallized from acetic acid: ethanol to afford desired product.

3 -(Benzylideneamino)-2,7-dimethyl-5,6,7,8-tetrahydropyrido $\left[4^{\prime}, 3^{\prime}: 4,5\right]$ thieno $[2,3-d]$ pyrimidin-4(3H)-one (7a)

Yield, $0.29 \mathrm{~g}(85 \%) . \mathrm{mp} 185-187^{\circ} \mathrm{C}$. IR $(\mathrm{KBr}) \mathrm{cm}^{-1}: 3066$ (aromatic $\mathrm{C}-\mathrm{H}$, str), 2957 (aliphatic $\mathrm{C}-\mathrm{H}$, str), $1640(\mathrm{C}=\mathrm{O}$, str), $1547(\mathrm{C}=\mathrm{N}$, str $) .{ }^{1} \mathrm{H}-\mathrm{NMR}\left(\mathrm{CDCl}_{3}\right) \delta$ (ppm): $2.53(3 \mathrm{H}$, $\left.\mathrm{s}, 7-\mathrm{NCH}_{3}\right), 2.62\left(3 \mathrm{H}, \mathrm{s}, 2-\mathrm{CH}_{3}\right.$ of pyrimidinone), $2.80(2 \mathrm{H}, \mathrm{t}$, $\left.J=5.83 \mathrm{~Hz}, 5-\mathrm{CH}_{2}\right), 3.16\left(2 \mathrm{H}, \mathrm{t}, J=5.81 \mathrm{~Hz}, 6-\mathrm{CH}_{2}\right), 3.65(2 \mathrm{H}$, $\left.\mathrm{s}, 8-\mathrm{CH}_{2}\right), 7.51\left(2 \mathrm{H}, \mathrm{t}, J=7.38 \mathrm{~Hz}, 3^{\prime}, 5^{\prime}-\mathrm{Ar}-\mathrm{H}\right), 7.56(1 \mathrm{H}, \mathrm{dt}$, $\left.J=2.67,1.85 \mathrm{~Hz}, 4^{\prime}-\mathrm{Ar}-\mathrm{H}\right), 7.90\left(2 \mathrm{H}, \mathrm{d}, J=7.07 \mathrm{~Hz}, 2^{\prime}, 6^{\prime}-\mathrm{Ar}-\mathrm{H}\right)$, $8.94(1 \mathrm{H}, \mathrm{s}, \mathrm{N}=\mathrm{CH})$. EI-MS (m/z;\%): $338\left(\mathrm{M}^{+} ; 31\right), 339$ $\left(\mathrm{M}^{+}+1 ; 6\right)$. Anal. Calcd for $\mathrm{C}_{17} \mathrm{H}_{16} \mathrm{~N}_{4} \mathrm{OS}: \mathrm{C}, 62.94 ; \mathrm{H}, 4.97 ; \mathrm{N}$, 17.27. Found: C, 63.06; H, 4.66; N, 17.16.

3-((4-Chlorobenzylidene)amino)-2,7-dimethyl-5,6,7,8-tetrahydropyrido $\left[4^{\prime}, 3^{\prime}: 4,5\right]$ thieno $[2,3-d]$ pyrimidin-4(3H)-one $(7 \mathbf{b})$

Yield, $0.26 \mathrm{~g}(71 \%)$. mp $153-155^{\circ} \mathrm{C}$. IR (KBr) cm $\mathrm{cm}^{-1}: 3069$ (aromatic C-H, str), 2919 (aliphatic $\mathrm{C}-\mathrm{H}$, str), $1672(\mathrm{C}=\mathrm{O}$, str), $1546(\mathrm{C}=\mathrm{N}, s t r) .{ }^{1} \mathrm{H}-\mathrm{NMR}\left(\mathrm{CDCl}_{3}\right) \delta(\mathrm{ppm}): 2.50(3 \mathrm{H}$, $\left.\mathrm{s}, 7-\mathrm{NCH}_{3}\right), 2.61\left(3 \mathrm{H}, \mathrm{s}, 2-\mathrm{CH}_{3}\right.$ of pyrimidinone), $2.84(2 \mathrm{H}$, t, $\left.J=5.88 \mathrm{~Hz}, 5-\mathrm{CH}_{2}\right), 3.18\left(2 \mathrm{H}, \mathrm{t}, J=5.91 \mathrm{~Hz}, 6-\mathrm{CH}_{2}\right), 3.68$ $\left(2 \mathrm{H}, \mathrm{s}, 8-\mathrm{CH}_{2}\right), 7.39\left(2 \mathrm{H}, \mathrm{d}, J=7.89 \mathrm{~Hz}, 3^{\prime}, 5^{\prime}-\mathrm{Ar}-\mathrm{H}\right), 7.50(2 \mathrm{H}$, d, $\left.J=7.98 \mathrm{~Hz}, 2^{\prime}, 6^{\prime}-\mathrm{Ar}-\mathrm{H}\right), 10.42(1 \mathrm{H}, \mathrm{s}, \mathrm{N}=\mathrm{CH}) .{ }^{13} \mathrm{C}-\mathrm{NMR}$ $\left(\mathrm{CDCl}_{3}\right) \delta$ (ppm): 22.52, 26.10, 45.45, 51.87, 53.74, 122.91, $129.29,129.72,130.15,131.62,132.12,138.41,145.68,156.46$, 160.81, 161.98. ESI-MS $(m / z ; \%): 374\left(\mathrm{M}^{+}+2 ; 33\right), 372\left(\mathrm{M}^{+}\right.$; 100). Anal. Calcd for $\mathrm{C}_{17} \mathrm{H}_{15} \mathrm{ClN}_{4} \mathrm{OS}: \mathrm{C}, 56.90 ; \mathrm{H}, 4.21 ; \mathrm{N}$, 15.61. Found: C, 56.52; H, 4.16; N, 15.16.
3-((4-Fluorobenzylidene)amino)-2,7-dimethyl-5,6,7,8-tetrahydropyrido $\left[4^{\prime}, 3^{\prime}: 4,5\right]$ thieno $[2,3-d]$ pyrimidin-4(3H)-one $(7 \mathrm{c})$

Yield, $0.23 \mathrm{~g}(65 \%) . \mathrm{mp} 230-232^{\circ} \mathrm{C}$. IR $(\mathrm{KBr}) \mathrm{cm}^{-1}: 3069$ (aromatic C-H, str), 2919 (aliphatic $\mathrm{C}-\mathrm{H}$, str), $1672(\mathrm{C}=\mathrm{O}$, str), $1601(\mathrm{C}=\mathrm{N}$, str $) .{ }^{1} \mathrm{H}-\mathrm{NMR}\left(\mathrm{CDCl}_{3}\right) \delta(\mathrm{ppm}): 2.50(3 \mathrm{H}$, $\left.\mathrm{s}, 7-\mathrm{CH}_{3}\right), 2.59\left(3 \mathrm{H}, \mathrm{s}, 2-\mathrm{CH}_{3}\right.$ of pyrimidinone), $2.77(2 \mathrm{H}, \mathrm{t}$, $\left.J=6 \mathrm{~Hz}, 5-\mathrm{CH}_{2}\right), 3.13\left(2 \mathrm{H}, \mathrm{t}, J=6 \mathrm{~Hz}, 6-\mathrm{CH}_{2}\right), 3.63(2 \mathrm{H}, \mathrm{s}$, $\left.8-\mathrm{CH}_{2}\right), 7.18\left(2 \mathrm{H}, \mathrm{t}, J=8.8 \mathrm{~Hz}, 3^{\prime}, 5^{\prime}-\mathrm{ArH}\right), 7.90(2 \mathrm{H}, \mathrm{dd}, J=5.6$, $\left.5.6 \mathrm{~Hz}, 2^{\prime}, 6^{\prime}-\mathrm{Ar}-\mathrm{H}\right), 8.91(1 \mathrm{H}, \mathrm{s}, \mathrm{N}=\mathrm{CH}) .{ }^{13} \mathrm{C}-\mathrm{NMR}\left(\mathrm{CDCl}_{3}\right)$ $\delta$ (ppm): 22.52, 25.97, 45.50, 51.94, 53.73, 116.14-116.36 (d), $120.85,128.90-128.93(d), 129.87,130.24,131.00-131.09(d)$, 153.99, 155.51, 161.19, 164.19, 165.76, 166.72. EI-MS ( $/ / z ; \%)$ : $356\left(\mathrm{M}^{+} ; 38\right), 234\left(\mathrm{M}^{+}-\mathrm{C}_{7} \mathrm{H}_{4} \mathrm{Cl}_{2} \mathrm{~N} ; 45\right), 192\left(\mathrm{M}^{+}-\mathrm{C}_{9} \mathrm{H}_{4} \mathrm{Cl}_{2} \mathrm{NO}\right.$; 100). Anal. Calcd for $\mathrm{C}_{17} \mathrm{H}_{15} \mathrm{FN}_{4} \mathrm{OS}$ : C, 59.63; H, 4.42; N, 16.36. Found: C, 59.22; H, 4.86; N, 16.06.

4-(((2,7-Dimethyl-4-oxo-5,6,7,8-tetrahydropyrido[ $\left[4^{\prime}, 3^{\prime}: 4,5\right]$ thieno[2,3-d]pyrimidin-3(4H)-yl)imino)methyl)benzonitrile (7d)

Yield, $0.25 \mathrm{~g}(68 \%) . \mathrm{mp} 200-202^{\circ} \mathrm{C}$. IR $(\mathrm{KBr}) \mathrm{cm}^{-1}: 3050$ (aromatic C-H, str), 2981 (aliphatic C-H, str), $2234(\mathrm{CN}$, str $), 1676(\mathrm{C}=\mathrm{O}$, str $), 1550(\mathrm{C}=\mathrm{N}$, str $) .{ }^{1} \mathrm{H}-\mathrm{NMR}\left(\mathrm{CDCl}_{3}\right) \delta$ (ppm): $2.52\left(3 \mathrm{H}, \mathrm{s}, 7-\mathrm{NCH}_{3}\right), 2.63\left(3 \mathrm{H}, \mathrm{s}, 2-\mathrm{CH}_{3}\right.$ of pyrimidinone), $2.79\left(2 \mathrm{H}, \mathrm{t}, J=5.22 \mathrm{~Hz}, 5-\mathrm{CH}_{2}\right), 3.14(2 \mathrm{H}, \mathrm{t}, J=5.54 \mathrm{~Hz}$, 6- $\left.\mathrm{CH}_{2}\right), 3.64\left(2 \mathrm{H}, \quad \mathrm{s}, \quad 8-\mathrm{CH}_{2}\right), 7.79(2 \mathrm{H}, \quad \mathrm{d}, \quad J=8.82 \mathrm{~Hz}$, 3',5'-Ar-H), $8.01\left(2 \mathrm{H}, \mathrm{d}, J=8.89 \mathrm{~Hz}, 2^{\prime}, 6^{\prime}-\mathrm{Ar}-\mathrm{H}\right), 9.22(1 \mathrm{H}$, $\mathrm{s}, \mathrm{N}=\mathrm{CH}) .{ }^{13} \mathrm{C}-\mathrm{NMR}\left(\mathrm{CDCl}_{3}\right) \delta(\mathrm{ppm}): 22.64,25.98,45.48$, 51.88, 53.69, 115.56, 118.02, 120.87, 129.02, 129.96, 130.68, $132.63,136.97,153.66,155.65,161.10,163.32$. ESI-MS $(\mathrm{m} / \mathrm{z}$; \%): $364\left(\mathrm{M}^{+}+1 ; 100\right)$. Anal. Calcd for $\mathrm{C}_{19} \mathrm{H}_{17} \mathrm{~N}_{5} \mathrm{OS}$ : C, 62.79; H, 4.71; N, 19.27. Found: C, 62.42; H, 4.86; N, 19.66.

3-((4-Methoxybenzylidene)amino)-2,7-dimethyl-5,6,7,8tetrahydropyrido $\left[4^{\prime}, 3^{\prime}: 4,5\right]$ thieno[2,3-d]pyrimidin-4(3H)-one (7e)

Yield, $0.31 \mathrm{~g}(82 \%) \cdot \mathrm{mp} 173-175^{\circ} \mathrm{C}$. IR $(\mathrm{KBr}) \mathrm{cm}^{-1}: 3095$ (aromatic C-H, str), 2921 (aliphatic $\mathrm{C}-\mathrm{H}$, str), $1684(\mathrm{C}=\mathrm{O}$, str) $1567(\mathrm{C}=\mathrm{N}$, str $) .{ }^{1} \mathrm{H}-\mathrm{NMR}\left(\mathrm{CDCl}_{3}\right) \delta$ (ppm): $2.53(3 \mathrm{H}, \mathrm{s}$, 7- $\left.\mathrm{NCH}_{3}\right), 2.60\left(3 \mathrm{H}, \mathrm{s}, 2-\mathrm{CH}_{3}\right.$ of pyrimidinone), $2.80(2 \mathrm{H}, \mathrm{t}$, $\left.J=5.82 \mathrm{~Hz}, 5-\mathrm{CH}_{2}\right), 3.16\left(2 \mathrm{H}, \mathrm{t}, J=5.79 \mathrm{~Hz}, 6-\mathrm{CH}_{2}\right), 3.66(2 \mathrm{H}$, s, 8- $\left.\mathrm{CH}_{2}\right), 3.91\left(3 \mathrm{H}, \mathrm{s}, \mathrm{Ar}-\mathrm{OCH}_{3}\right), 7.01(2 \mathrm{H}, \mathrm{d}, J=8.81 \mathrm{~Hz}$, $\left.3^{\prime}, 5^{\prime}-\mathrm{Ar}-\mathrm{H}\right), 7.86\left(2 \mathrm{H}, \mathrm{d}, J=8.80 \mathrm{~Hz}, 2^{\prime}, 6^{\prime}-\mathrm{Ar}-\mathrm{H}\right), 8.75(1 \mathrm{H}$, $\mathrm{s}, \mathrm{N}=\mathrm{CH}) .{ }^{13} \mathrm{C}-\mathrm{NMR}\left(\mathrm{CDCl}_{3}\right) \delta(\mathrm{ppm}): 22.66,26.10,45.46$, 51.91, 53.76, 55.44, 114.43, 122.92, 125.47, 130.07, 130.57, $131.76,145.28,156.19,160.93,163.12,164.29$. EI-MS ( $m / z ; \%)$ : $368\left(\mathrm{M}^{+} ; 18\right), 192\left(\mathrm{M}^{+}-\mathrm{C}_{10} \mathrm{H}_{9} \mathrm{O}_{2} \mathrm{~N} ; 15\right), 57\left(\mathrm{M}^{+}-\mathrm{C}_{16} \mathrm{H}_{13} \mathrm{~N}_{3} \mathrm{O}_{2} \mathrm{~S}\right.$; 100). Anal. Calcd for $\mathrm{C}_{19} \mathrm{H}_{20} \mathrm{~N}_{4} \mathrm{O}_{2} \mathrm{~S}$ : C, 61.94; H, 5.47; N, 15.21. Found: C, 61.58; H, 5.12; N, 15.06.

3-((4-Hydroxybenzylidene)amino)-2,7-dimethyl-5,6,7,8-tetrahydropyrido $\left[4^{\prime}, 3^{\prime}: 4,5\right]$ thieno $[2,3-d]$ pyrimidin-4(3H)-one (7f)

Yield, $0.27 \mathrm{~g}(76 \%)$ mp $218-220^{\circ} \mathrm{C}$. IR (KBr) $\mathrm{cm}^{-1}: 3250$ (aromatic C-H, str), 2949 (aliphatic $\mathrm{C}-\mathrm{H}, s t r), 1647(\mathrm{C}=\mathrm{O}$, str), $1546(\mathrm{C}=\mathrm{N}$, str $) .{ }^{1} \mathrm{H}-\mathrm{NMR}\left(\mathrm{CDCl}_{3}\right) \delta(\mathrm{ppm}): 2.41(3 \mathrm{H}$, $\left.\mathrm{s}, 7-\mathrm{NCH}_{3}\right), 2.48\left(3 \mathrm{H}, \mathrm{s}, 2-\mathrm{CH}_{3}\right.$ of pyrimidinone $), 2.71(2 \mathrm{H}$, t, $\left.J=5.86 \mathrm{~Hz}, 5-\mathrm{CH}_{2}\right), 2.97\left(2 \mathrm{H}, \mathrm{t}, J=5.80 \mathrm{~Hz}, 6-\mathrm{CH}_{2}\right), 3.59$ $\left(2 \mathrm{H}, \mathrm{s}, 8-\mathrm{CH}_{2}\right), 6.98\left(2 \mathrm{H}, \mathrm{d}, J=5.14 \mathrm{~Hz}, 3^{\prime}, 5^{\prime}-\mathrm{Ar}-\mathrm{H}\right), 7.84(2 \mathrm{H}$, d, $\left.J=8.32 \mathrm{~Hz}, 2^{\prime}, 6^{\prime}-\mathrm{Ar}-\mathrm{H}\right), 8.67(1 \mathrm{H}, \mathrm{s}, \mathrm{N}=\mathrm{CH}), 10.47(1 \mathrm{H}$, $\mathrm{s}, \mathrm{Ar}-\mathrm{OH}) .{ }^{13} \mathrm{C}-\mathrm{NMR}\left(\mathrm{CDCl}_{3}\right) \delta$ (ppm): 22.51, 26.13, 45.48, 51.90, 53.77, 122.91, 129.32, 129.76, 130.18, 131.64, 132.15, $138.45,145.70,156.49,160.85,162.03$. ESI-MS $(m / z ; \%): 355$ $\left(\mathrm{M}^{+}+1 ; 100\right)$. Anal. Calcd for $\mathrm{C}_{18} \mathrm{H}_{18} \mathrm{~N}_{4} \mathrm{O}_{2} \mathrm{~S}: \mathrm{C}, 61.00 ; \mathrm{H}, 5.12$; N, 15.81. Found: C, 61.38; H, 4.96; N, 16.12. 
2,7-Dimethyl-3-((3,4,5-trimethoxybenzylidene)amino)$5,6,7,8$-tetrahydropyrido $\left[4^{\prime}, 3^{\prime}: 4,5\right]$ thieno $[2,3-d]$ pyrimidin4(3H)-one $(7 \mathbf{g})$

Yield, $0.3 \mathrm{~g}(70 \%) . \mathrm{mp} 198-200^{\circ} \mathrm{C}$. IR $(\mathrm{KBr}) \mathrm{cm}^{-1}: 3059$ (aromatic $\mathrm{C}-\mathrm{H}$, str), 2937 (aliphatic $\mathrm{C}-\mathrm{H}$, str), $1672(\mathrm{C}=\mathrm{O}$, str), $1576(\mathrm{C}=\mathrm{N}$, str $) .{ }^{1} \mathrm{H}-\mathrm{NMR}\left(\mathrm{CDCl}_{3}\right) \delta(\mathrm{ppm}): 2.53(3 \mathrm{H}$, $\left.\mathrm{s}, 7-\mathrm{NCH}_{3}\right), 2.62\left(3 \mathrm{H}, \mathrm{s}, 2-\mathrm{CH}_{3}\right.$ of pyrimidinone $), 2.80(2 \mathrm{H}$, t, $\left.J=5.81 \mathrm{~Hz}, 5-\mathrm{CH}_{2}\right), 3.16\left(2 \mathrm{H}, \mathrm{t}, J=5.76 \mathrm{~Hz}, 6-\mathrm{CH}_{2}\right), 3.66$ $\left(2 \mathrm{H}, \mathrm{s}, 8-\mathrm{CH}_{2}\right), 3.94\left(6 \mathrm{H}, \mathrm{s}, 3^{\prime}, 5^{\prime}-\mathrm{Ar}-\mathrm{OCH}_{3}\right), 3.96(3 \mathrm{H}, \mathrm{s}$, $4^{\prime}$-Ar- $\left.\mathrm{OCH}_{3}\right), 7.16\left(2 \mathrm{H}, \mathrm{s}, 2^{\prime}, 6^{\prime}-\mathrm{Ar}-\mathrm{H}\right), 8.77(1 \mathrm{H}, \mathrm{s}, \mathrm{N}=\mathrm{CH})$. ${ }^{13} \mathrm{C}-\mathrm{NMR}\left(\mathrm{CDCl}_{3}\right) \delta$ (ppm): 22.48, 25.97, 45.47, 51.93, 53.71, $56.29,60.99,106.28,120.81,127.60,129.85,130.15,142.29$, $153.36,153.60,155.49,161.21,167.28$. ESI-MS $(\mathrm{m} / \mathrm{z} ; \%): 429$ $\left(\mathrm{M}^{+}+1 ; 100\right)$. Anal. Calcd for $\mathrm{C}_{21} \mathrm{H}_{24} \mathrm{~N}_{4} \mathrm{O}$ S: C, 58.86; H, 5.65; $\mathrm{N}, 13.07$. Found: C, 58.58; H, 5.26; N, 13.12.

2,7-Dimethyl-3-((2-nitrobenzylidene)amino)-5,6,7,8-tetrahydropyrido $\left[4^{\prime}, 3^{\prime}: 4,5\right]$ thie no[2,3-d]pyrimidin-4(3H)-one (7h)

Yield, $0.3 \mathrm{~g}$ (78\%). mp $154-156^{\circ} \mathrm{C}$. IR $(\mathrm{KBr}) \mathrm{cm}^{-1}$ : 3019 (aromatic C-H, str), 2932 (aliphatic C-H, str), 1686 $(\mathrm{C}=\mathrm{O}$, str $), 1524(\mathrm{C}=\mathrm{N}$, str $) .{ }^{1} \mathrm{H}-\mathrm{NMR}\left(\mathrm{CDCl}_{3}\right) \delta$ (ppm): $2.51\left(3 \mathrm{H}, \mathrm{s}, 7-\mathrm{NCH}_{3}\right), 2.62\left(3 \mathrm{H}, \mathrm{s}, 2-\mathrm{CH}_{3}\right.$ of pyrimidinone), $2.79\left(2 \mathrm{H}, \mathrm{t}, J=6 \mathrm{~Hz}, 5-\mathrm{CH}_{2}\right), 3.24\left(2 \mathrm{H}, \mathrm{t}, J=6 \mathrm{~Hz}, 6-\mathrm{CH}_{2}\right)$, $3.67\left(2 \mathrm{H}, \mathrm{s}, 8-\mathrm{CH}_{2}\right), 7.66\left(1 \mathrm{H}, \mathrm{dt}, J=8.12 \mathrm{~Hz}, 4^{\prime}-\mathrm{Ar}-\mathrm{H}\right)$, $7.80\left(1 \mathrm{H}, \mathrm{dt}, J=8.12 \mathrm{~Hz}, 5^{\prime}-\mathrm{Ar}-\mathrm{H}\right), 8.20(2 \mathrm{H}, \mathrm{dd}, J=8.34$, $\left.1.46 \mathrm{~Hz}, 3^{\prime}, 6^{\prime}-\mathrm{Ar}-\mathrm{H}\right), 9.44(1 \mathrm{H}, \mathrm{s}, \mathrm{N}=\mathrm{CH})$. ESI-MS $(\mathrm{m} / \mathrm{z} ; \%)$ : $384\left(\mathrm{M}^{+}+1 ; 26\right), 340\left(\mathrm{M}^{+}-\mathrm{C}_{2} \mathrm{H}_{3} \mathrm{O} ; 100\right)$. Anal. Calcd for $\mathrm{C}_{18} \mathrm{H}_{17} \mathrm{~N}_{5} \mathrm{O}_{3} \mathrm{~S}$ : C, 56.38; H, 4.47; N, 18.27. Found: C, 56.48; H, $4.91 ; \mathrm{N}, 17.98$.

2,7-Dimethyl-3-((thiophen-2-ylmethylene)amino)-5,6,7,8tetrahydropyrido $\left[4^{\prime}, 3^{\prime}: 4,5\right]$ thieno $[2,3-d]$ pyrimidin-4(3H)-one (7i)

Yield, $0.24 \mathrm{~g}(70 \%) . \mathrm{mp} 178-180^{\circ} \mathrm{C}$. IR $(\mathrm{KBr}) \mathrm{cm}^{-1}: 3051$ (aromatic C-H, str), 2938, 2785 (aliphatic C-H, str), 1683 $(\mathrm{C}=\mathrm{O}$, str $), 1581(\mathrm{C}=\mathrm{N}$, str $) .{ }^{1} \mathrm{H}-\mathrm{NMR}\left(\mathrm{CDCl}_{3}\right) \delta(\mathrm{ppm}): 2.53$ $\left(3 \mathrm{H}, \mathrm{s}, 7-\mathrm{NCH}_{3}\right), 2.62\left(3 \mathrm{H}, \mathrm{s}, 2-\mathrm{CH}_{3}\right.$ of pyrimidinone), 2.80 $\left(2 \mathrm{H}, \mathrm{t}, J=5.82 \mathrm{~Hz}, 5-\mathrm{CH}_{2}\right), 3.16\left(2 \mathrm{H}, \mathrm{t}, J=5.80 \mathrm{~Hz}, 6-\mathrm{CH}_{2}\right)$, $3.65\left(2 \mathrm{H}, \mathrm{s}, 8-\mathrm{CH}_{2}\right), 7.18\left(1 \mathrm{H}, \mathrm{dd}, J=5.00,3.70 \mathrm{~Hz}, 4^{\prime}-\mathrm{Ar}-\mathrm{H}\right)$, $7.58\left(1 \mathrm{H}, \mathrm{dd}, J=3.67,1.01 \mathrm{~Hz}, 5^{\prime}-\mathrm{Ar}-\mathrm{H}\right), 7.61(1 \mathrm{H}, \mathrm{td}, J=4.97$, $\left.0.90 \mathrm{~Hz}, 3{ }^{\prime}-\mathrm{Ar}-\mathrm{H}\right), 9.13(1 \mathrm{H}, \mathrm{s}, \mathrm{N}=\mathrm{CH}) .{ }^{13} \mathrm{C}-\mathrm{NMR}\left(\mathrm{CDCl}_{3}\right) \delta$ (ppm): 22.51, 25.76, 49.83, 51.59, 61.96, 112.49, 118.66, 127.33, $128.40,129.10,130.25,137.92,146.85,153.55,155.02,155.53$, 161.16. ESI-MS $(m / z ; \%): 315\left(\mathrm{M}^{+}-\mathrm{CO} ; 92\right), 344.9\left(\mathrm{M}^{+}+1\right.$; 45). Anal. Calcd for $\mathrm{C}_{16} \mathrm{H}_{16} \mathrm{~N}_{4} \mathrm{OS}_{2}$ : C, 55.79; H, 4.68; N, 16.27. Found: C, 55.88; H, 4.61; N, 16.32.

3-((Furan-2-ylmethylene)amino)-2,7-dimethyl-5,6,7,8-tetrahydropyrido $\left[4^{\prime}, 3^{\prime}: 4,5\right]$ thieno $[2,3-d]$ pyrimidin-4(3H)-one $(7 \mathbf{j})$

Yield, $0.26 \mathrm{~g}(79 \%) . \mathrm{mp} 172-174^{\circ} \mathrm{C}$. IR (KBr) $\mathrm{cm}^{-1}: 3123$ (aromatic C-H, str), 2936, 2803 (aliphatic C-H, str), 1671 $(\mathrm{C}=\mathrm{O}$, str $), 1557(\mathrm{C}=\mathrm{N}$, str $) .{ }^{1} \mathrm{H}-\mathrm{NMR}\left(\mathrm{CDCl}_{3}\right) \delta$ (ppm): 2.51 $\left(3 \mathrm{H}, \mathrm{s}, 7-\mathrm{NCH}_{3}\right), 2.60\left(3 \mathrm{H}, \mathrm{s}, 2-\mathrm{CH}_{3}\right.$ of pyrimidinone), 2.77 $\left(2 \mathrm{H}, \mathrm{t}, J=5.98 \mathrm{~Hz}, 5-\mathrm{CH}_{2}\right), 3.13\left(2 \mathrm{H}, \mathrm{t}, J=5.61 \mathrm{~Hz}, 6-\mathrm{CH}_{2}\right)$, $3.62\left(2 \mathrm{H}, \mathrm{s}, 8-\mathrm{CH}_{2}\right), 6.60\left(1 \mathrm{H}, \mathrm{t}, J=1.22 \mathrm{~Hz}, 4^{\prime}-\mathrm{Ar}-\mathrm{H}\right.$ of furan), $7.26\left(1 \mathrm{H}, \mathrm{d}, J=3.22 \mathrm{~Hz}, 3^{\prime}-\mathrm{Ar}-\mathrm{H}\right.$ of furan $), 7.68(1 \mathrm{H}, \mathrm{d}$, $J=3.22 \mathrm{~Hz}, 5^{\prime}-\mathrm{Ar}-\mathrm{H}$ of furan), $8.77(1 \mathrm{H}, \mathrm{s}, \mathrm{N}=\mathrm{CH})$. ESI-MS $(m / z ; \%): 329\left(\mathrm{M}^{+}+1 ; 100\right)$. Anal. Calcd for $\mathrm{C}_{16} \mathrm{H}_{16} \mathrm{~N}_{4} \mathrm{O}_{2} \mathrm{~S}: \mathrm{C}$, 58.52; H, 4.91; N, 17.06. Found: C, 58.48; H, 4.61; N, 16.72 .

3-((2,4-Dichlorobenzylidene)amino)-2,7-dimethyl-5,6,7,8tetrahydropyrido $\left[4^{\prime}, 3^{\prime}: 4,5\right]$ thieno $[2,3-d]$ pyrimidin- $4(3 H)$-one (7k)

Yield, $0.32 \mathrm{~g}(80 \%) . \mathrm{mp} 181-183^{\circ} \mathrm{C}$. IR (KBr) $\mathrm{cm}^{-1}: 3083$ (aromatic C-H, str), 2938 (aliphatic $\mathrm{C}-\mathrm{H}$, str), $1681(\mathrm{C}=\mathrm{O}$, str), $1582(\mathrm{C}=\mathrm{N}$, str $) .{ }^{1} \mathrm{H}-\mathrm{NMR}\left(\mathrm{CDCl}_{3}\right) \delta(\mathrm{ppm}): 2.54(3 \mathrm{H}$, $\left.\mathrm{s}, 7-\mathrm{NCH}_{3}\right), 2.63\left(3 \mathrm{H}, \mathrm{s}, 2-\mathrm{CH}_{3}\right.$ of pyrimidinone $), 2.80(2 \mathrm{H}$, t, $\left.J=5.79 \mathrm{~Hz}, 5-\mathrm{CH}_{2}\right), 3.17\left(2 \mathrm{H}, \mathrm{t}, J=5.82 \mathrm{~Hz}, 6-\mathrm{CH}_{2}\right), 3.66$ $\left(2 \mathrm{H}, \mathrm{s}, 8-\mathrm{CH}_{2}\right), 7.39\left(1 \mathrm{H}, \mathrm{dd}, J=8.51,1.50 \mathrm{~Hz}, 5^{\prime}-\mathrm{Ar}-\mathrm{H}\right), 7.51$ $\left(1 \mathrm{H}, \mathrm{d}, J=1.99 \mathrm{~Hz}, 3^{\prime}-\mathrm{Ar}-\mathrm{H}\right), 8.17\left(1 \mathrm{H}, \mathrm{d}, J=8.48 \mathrm{~Hz}, 6^{\prime}-\mathrm{Ar}-\mathrm{H}\right)$, $9.42(1 \mathrm{H}, \mathrm{s}, \mathrm{N}=\mathrm{CH}) .{ }^{13} \mathrm{C}-\mathrm{NMR}\left(\mathrm{CDCl}_{3}\right) \delta(\mathrm{ppm}): 22.51,26.14$, $45.44,51.84,53.73,122.93,127.74,128.45,129.60,129.98$, 130.30, 132.17, 136.80, 138.56, 145.80, 156.40, 158.37, 166.67. EI-MS (m/z;\%): $408\left(\mathrm{M}^{+}+2,14\right), 406\left(\mathrm{M}^{+} ; 20\right), 234\left(\mathrm{M}^{+}-\right.$ $\left.\mathrm{C}_{7} \mathrm{H}_{4} \mathrm{Cl}_{2} \mathrm{~N} ; 45\right), 192\left(\mathrm{M}^{+}-\mathrm{C}_{9} \mathrm{H}_{4} \mathrm{Cl}_{2} \mathrm{NO} ; 100\right)$. Anal. Calcd for $\mathrm{C}_{18} \mathrm{H}_{16} \mathrm{Cl}_{2} \mathrm{~N}_{4} \mathrm{OS}$ : C, 53.08; H, 3.96; N, 13.76. Found: C, 52.86; $\mathrm{H}, 3.67 ; \mathrm{N}, 14.52$.

Antibacterial Activity The synthesized final compounds were screened for their in vitro antibacterial activity against mentioned strains of Gram-positive and Gram-negative bacteria. The MIC values were determined by employing similar techniques of our studies, ${ }^{5)}$ and the results were compared with standard (streptomycin). The MIC values were expressed in micro moles $(\mu \mathrm{M})$ and the results were listed in Table 1.

Antimycobacterial Activity The MTB H37Rv and an INH-resistant clinical sample of Mycobacteria were used for screening and the MIC values were determined using a broth micro dilution method as described in our previous protocols. ${ }^{5}$ The stock solution of all compounds was prepared in the concentration of $1 \mathrm{mg} / \mathrm{mL}$ dissolved in DMF in water $(25 \% \mathrm{v} / \mathrm{v})$. About ten test concentrations ranging from $1000-1 \mu \mathrm{g} / \mathrm{mL}$ were used to assess the efficacy of each compound.

Molecular Docking The molecular docking studies were performed using Molegro Virtual Docker (MVD) tools24 on targeted protein MTB-PS (PDB: 3IVX).

Acknowledgments One of the authors (MN) thanks UGC-BSR (No. F.7-106/2007) for providing a merit scholarship. The authors are thankful to the Principal, University College of Pharmaceutical Sciences (UCPSc), Kakatiya University for providing facilities and also Principal and Management, Sri Shivani College of Pharmacy, Warangal for permitting to carry out the biological activity.

Conflict of Interest The authors declare no conflict of interest.

Supplementary Materials The online version of this article contains supplementary materials.

\section{References}

1) WHO, "Global tuberculosis report.”: 〈http://www.who.int/tb/ publications», 2014.

2) Szumowski J. D., Lynch J. B., Drug Des. Devel. Ther., 9, 677-682 (2015).

3) Salvador M. K., Baraldi P. G., Romagnoli R., Drug Discov. Today. Technol., 10, 285-296 (2013).

4) Lienhardt C., Vernon A., Raviglione M. C., Curr. Opin. Pulm. Med., 16, 186-193 (2010).

5) Malothu N., Bhandaru J. S., Kulandaivelu U., Jojula M., Adidala R. R., Umadevi K. R., Dusthackeer A. V. N., Kaki V. R., Akkinepally R. R., Bioorg. Med. Chem. Lett., 26, 836-840 (2015).

6) Robert C. R., Subramaniam A., Ellen F., Judith V. H., Cecil D. K. Clinton M., Lynn R., Melinda I. S., Elizabeth T., Lucile W. E., We Z., John A. S. III, Tuberculosis, 92, 72-83 (2012).

7) Rashmi P., Nargund L. V. G., Hazra K., Chandra J. N. N., S. Arch. Pharm. Chem. Life Sci., 344, 459-465 (2011). 
8) Narayana B., Ashalatha B. V., Raj K. K. V., Kumari N. S., Indian J. Chem., 45B, 2696-2703 (2006).

9) Aurelio L., Valant C., Figler H., Flynn B. L., Linden J., Sexton P. M., Christopoulos A., Scammell P. J., Bioorg. Med. Chem., 17, 7353-7361 (2009).

10) Puterova Z., Krutosikova A., Vegh D., ARKIVOC, 1, 209-246 (2010).

11) El-Kashef H., Farghaly A. R., Al-Hazmi A., Terme T., Vanelle P., Molecules, 15, 2651-2666 (2010).

12) Al-Taisan K. M., Al-Hazimi H. M. A., Al-Shihry S. S., Molecules, 15, 3932-3957 (2010).

13) Nitinkumar S. S., Ravi S. L., Imtiyaz A. M. K., J. Chem. Sci., 121,
301-307 (2009)

14) Chambhare R. V., Khadse B. G., Bobde A. S., Bahekar R. H., Eur. J. Med. Chem., 38, 89-100 (2003).

15) Dewal M. B., Wani A. S., Vidaillac C., Oupický D., Rybak M. J., Firestine S. M., Eur. J. Med. Chem., 51, 145-153 (2012).

16) Raghavendra N. M., Thampi P., Gurubasavarajaswamy P. M., Sriram D., Arch. Pharm. Chem. Life Sci, 340, 635-641 (2007).

17) Tran T., Saheba E., Arcerio A. V., Chavez V., Li Q., Martinez L. E., Primm T. P., Bioorg. Med. Chem., 12, 4809-4813 (2004).

18) Wang S., Eisenberg D., Protein Sci., 12, 1097-1108 (2003).

19) Hung A. W., Silvestre H. L., Wen S., Ciulli A., Blundell T. L., Abell C., Angew. Chem. Int. Ed., 48, 8452-8456 (2009). 